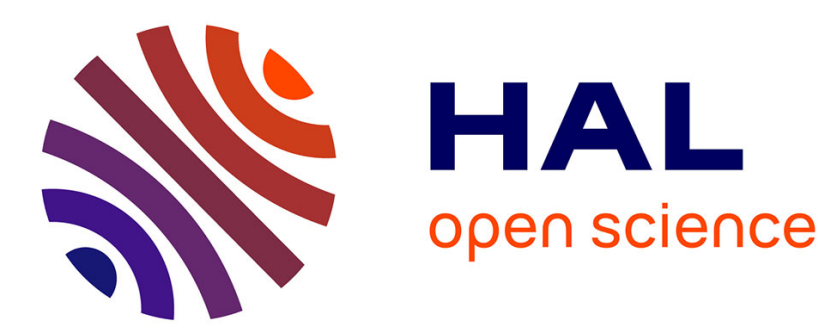

\title{
Ownership Structure and Risk in Publicly Held and Privately Owned Banks
}

Thierno Amadou Barry, Laetitia Lepetit, Amine Tarazi

\section{To cite this version:}

Thierno Amadou Barry, Laetitia Lepetit, Amine Tarazi. Ownership Structure and Risk in Publicly Held and Privately Owned Banks. Journal of Banking and Finance, 2011, 35 (5), pp.1237-1340. 10.1016/j.jbankfin.2010.10.004 . hal-00918543

\section{HAL Id: hal-00918543 \\ https://hal-unilim.archives-ouvertes.fr/hal-00918543}

Submitted on 16 Dec 2013

HAL is a multi-disciplinary open access archive for the deposit and dissemination of scientific research documents, whether they are published or not. The documents may come from teaching and research institutions in France or abroad, or from public or private research centers.
L'archive ouverte pluridisciplinaire HAL, est destinée au dépôt et à la diffusion de documents scientifiques de niveau recherche, publiés ou non, émanant des établissements d'enseignement et de recherche français ou étrangers, des laboratoires publics ou privés. 


\title{
OWNERSHIP STRUCTURE AND RISK IN PUBLICLY HELD AND PRIVATELY OWNED BANKS
}

\author{
Thierno Amadou Barry, Laetitia Lepetit and Amine Tarazi ${ }^{1}$ \\ Université de Limoges, LAPE, 5 rue Félix Eboué, 87031 Limoges Cedex, France
}

November 2009

\begin{abstract}
Using detailed ownership data for a sample of European commercial banks, we analyze the link between ownership structure and risk in both privately owned and publicly held banks. We consider five categories of shareholders (managers/directors, institutional investors, non-financial companies, individuals/families, and banks), a breakdown specific to our dataset. Controlling for various factors, we find that ownership structure is significant in explaining risk differences but that such findings mainly hold for privately owned banks. On the whole, a higher equity stake of either individuals/families or banking institutions is associated with a decrease in asset risk and default risk. Also, institutional investors and non-financial companies seem to impose the riskiest strategies when they hold higher stakes. We further find no significant differences in asset risk and default risk between publicly-held and privately-owned banks. Moreover, for public banks, changes in ownership structure do not affect risk taking. Market forces seem to align the risk-taking behavior of public banks and the ownership structure is no more a determinant to explain risk differences. An exception is that higher stakes of banking institutions in public banks are associated with lower credit and default risk.
\end{abstract}

Keywords: Ownership structure, bank risk, European banks, Market Discipline JEL Classification: G21, G32

\footnotetext{
1 Corresponding authors: Tel: +33-555-14-92-08, thierno.barry@unilim.fr (T. Barry); laetitia.lepetit@unilim.fr (L. Lepetit); amine.tarazi@unilim.fr (A. Tarazi).
} 


\section{Introduction}

The last three decades have been characterized by repeated banking crises (the financial crisis of 2008, the US savings and loans debacle of the eighties, the 1994-95 Mexican crisis, the 1997 Asian and 1998 Russian financial crises...). Such episodes highlight the inherently unstable nature of banking and the tendency that banks have towards excessive risk taking. In this paper, we aim to focus on one of the driving forces behind the risk-taking incentives of banks, namely shareholders' behavior and their incentives to take higher risk. The issue of ownership structure is of particular interest for the banking industry as several factors interact and alter governance, such as the quality of bank regulation and supervision and the opacity of bank assets. Moreover, banking systems faced major changes during the last 20 years. With financial deregulation and market integration, the scope of activities of banks has been completely reshaped ranging from traditional intermediation products to an array of new businesses. These trends led to substantial consolidation in the banking industry and consequently to significant changes in ownership and capital structure. Also, institutional ownership of common stock has increased substantially over the past twenty years. This might also imply changes in corporate governance and in banks' behavior in terms of risk taking.

However, it is also well known that because of greater separation of ownership and control, firms with publicly held equity face different agency problems than privately held firms. Furthermore, for publicly traded banks, risk-taking incentives can be influenced by market forces. On the one hand, the market is expected to monitor or to influence the risk behavior of banks and therefore the impact of ownership changes on risk cannot be assessed without considering incentives driven by financial markets in terms of discipline (Bliss and Flannery, 2002; Flannery, 2001). In the new Basel Capital Accord, market discipline is one of the three pillars, along with capital regulation (first pillar) and banking supervision (second pillar). The idea is to rely on market forces to enhance banking supervision or to mitigate shareholders' risk taking incentives and consequently market discipline is expected to play an important role for publicly held banks and to some extent for private banks that are strongly reliant on market debt. On the other hand, banks that are prone to become public might have different objectives in terms of growth and risk-return strategies. Public equity is more liquid than private equity and can thus be raised at 
lower cost. Hence, if publicly owned banks' purpose to access capital markets is to finance faster growth opportunities, they are more likely to take on more risk than privately owned banks.

To our knowledge there has been no research on whether risk might be different for privately-owned banks and publicly-held banks under specific ownership profiles. Kwan (2004), working on a sample of US bank holding companies (BHC), finds that loan quality and earnings variability are not different between traded BHCs and privately held BHCs. One of our aims in this paper is to assess the risk-taking behavior of banks by combining the two interrelated dimensions of ownership structure and market discipline.

It has been stressed in the theoretical and empirical literature that agency problems and risk-taking behavior are different according to the nature of the shareholder. A first issue is the conflict of interest between managers and shareholders identified by Jensen and Meckling (1976). Theory indicates that shareholders with a diversified portfolio are motivated to take more risk for a higher expected return whereas managers take less risk to protect their position and personal benefits, and preserve their acquired human capital (Galai and Masulis, 1976; Jensen and Meckling, 1976; Demsetz and Lehn, 1985; Esty, 1998). Empirically, Saunders et al (1990) are the first to test the relationship between banks' ownership structure and their risk-taking incentives. They find a positive relationship between managerial stock ownership (proportion of stock held by managers) and risk taking. Moreover, they find that banks controlled by shareholders take more risk than banks controlled by managers. A number of studies, following Saunders et al. (1990), find a significant effect of ownership concentration on risk-taking but without any consensus on the sign of such a relationship. If some studies find a negative relationship, others obtain U-shaped relationships (or inverse U-shaped) between ownership concentration and risk (Gorton and Rosen, 1995; Chen, et al., 1998; Anderson and Fraser, 2000). Ushaped relationships between ownership and risk taking could be explained by managers' entrenchment. Moreover, Sullivan and Spong (2007) show that stock ownership by hired managers is positively linked with bank risk, meaning that under certain conditions hired managers operate their bank more closely in line with stockholder interests.

Another issue well developed in the literature is the comparison of the performance (profitability and asset quality) of state-owned banks compared to their 
private counterparts. Agency costs within government bureaucracy can result in weak managerial incentives and misallocation of resources. According to the agency cost view, managers exert less effort than their private counterparts or divert resources for personal benefits, such as, for example, career concerns. For the political view of state ownership, government-owned banks are inefficient because of the politicians' deliberate policy of transferring resources to their supporters (Shleifer, 1998; Shleifer and Vishny, 1986). It has been underlined that state-owned banks have poorer loan quality and higher default risk than private-owned banks (Berger et al., 2005; Iannotta et al., 2007). Iannota et al, 2007 also highlight that mutual banks and governmentowned banks appear as less profitable than private-owned banks. Moreover, they find that government-owned banks have poorer loan quality and higher default risk, while mutual banks have better loan quality and lower asset risk than both private-owned and government-owned banks. In addition, some papers have shown that foreignowned banks exhibit a higher performance than other banks, particularly in developing countries (Claessens et al., 2001; Bonin et al, 2005; Micco et al., 2007).

Beside the issues of the manager owner conflict and the differences between state-owned and private-owned firms, there are other aspects that are well developed in the literature on non-financial firms but not in the literature on financial firms. First, institutional investors (investment companies, investment advisors, pension funds...) who exercise significant voting power can shape the nature of corporate risk taking. In terms of shareholding size, expertise in processing information and monitoring managers, such investors are very different from atomistic individual investors. Institutional investors can exert greater control for reasons of economies of scale in corporate supervision. Pound (1988) highlights that institutional investors can exercise a control at a lower cost as they have more experience. There is also the possibility, however, that managers and institutional investors form an alliance, so that insider interests could take priority over the maximization of firm value. At the same time, as institutional investors have a diversified portfolio of investments, they may have lower incentives to exercise control. Empirical evidence (Acker and Athanassakos, 2003), based on non-financial firms, does not provide conclusive results on the effect of control by institutional investors on firm value. Second, family-owned firms are perceived as less willing to take risk but also as less profitable. More generally, firms with large, undiversified owners such as founding families may forgo maximum profits because their wealth is not sufficiently 
diversified. Families also limit executive management positions to family members, suggesting a restricted labor pool from which to obtain qualified and capable talent, potentially leading to competitive disadvantages relatively to non-family-owned firms (Morck et al, 2000). However, James (1999) posits that families have longer investment horizons leading to greater investment efficiency. Stein (1988, 1989) shows that the presence of shareholders with relatively long investment horizons can mitigate the incentives for myopic investment decisions by managers. Regarding the banking industry, few papers analyze this issue. Laeven (1999) considers different forms of bank ownership including state-owned, foreign-owned, company-owned and family-owned banks but not banks owned by institutional investors. Working on a panel of Asian banks before the Asian crisis of 1997, he finds that family-owned banks were among the most risky banks together with company-owned banks whereas foreign-owned banks took little risk relatively to other banks.

The objective of this paper is to extend the current literature which analyzes how ownership structure affects bank risk taking and profitability in several directions. First, we work on a broader classification of shareholders by considering the equity held by managers, individuals/families, non-financial companies, but also the equity held by institutional investors and by banks. Second, we consider the proportion of equity held by each category of owner instead of using dummy variables to divide ownership into mutually exclusive categories as in most of the previous studies on bank ownership (Berger et al., 2005; Bonin et al., 2005; Boubakri et al., 2005; Williams and Nguyen, 2005). We are therefore able to measure the level of ownership dispersion/concentration within each of the five categories of shareholders we consider. We can hence check if the level of ownership dispersion matters when assessing the relationship between ownership structure and bank risk/profitability. Working with continuous variables instead of binary variables also enables us to analyze how the interaction of equity held by different types of shareholders influences the risk-taking behavior of banks. It allows us to study the link between ownership structure and risk more thoroughly by dealing with the issue of possible coalitions among different categories or groups. Nevertheless, for consistency with previous studies we also study the link between risk and the nature of the main shareholder. Third, by investigating the link between ownership structure and risk for both listed (publicly held) and non-listed (privately owned) banks we 
question the ability of market forces to influence bank risk-taking behavior (market discipline) under different ownership arrangements. Fourth, previous studies that use a detailed breakdown of the stakes held by different categories of owners were mostly dedicated to US banks and could not consider as many categories of shareholders because ownership of banks by non-financial companies is not permitted. By working on European banks we are therefore able to introduce an additional category, nonfinancial firms, which the literature considers as playing a very controversial role in influencing the management of financial institutions. Studies on European banks have focused on the nature of ownership (public, private, mutual, cooperative...) rather than on the structure of ownership in private banks. In this paper we consider only one category of banks. We focus on commercial banks because they are assumed to have homogeneous objective functions, and to our knowledge this is the first study that looks into the relationship between ownership structure and risk for European commercial banks.

We work on a panel of European banks through the period 1999-2005. Our results show that different ownership structures imply different levels of risk and profitability, but such findings mainly hold for privately owned banks. Publicly-held banks with different ownership structures do not present different levels of risk and profitability, suggesting that market forces might be aligning the risk behavior of such banks.

The remainder of the paper is structured as follows. Section 2 describes our data and variables. Section 3 presents the methodology and the hypotheses tested. The empirical results are discussed in section 4. Section 5 reports robustness checks and discusses further issues. Section 6 concludes the paper.

\section{Data, variables and descriptive statistics}

\subsection{Data collection and sample definition}

The annual data used in this paper are taken from Bankscope Fitch IBCA which provides information on financial statements and ownership structure for financial institutions worldwide. We collect the percentage of stocks held by shareholders by considering the following items: managers/directors, institutional investors, non-financial companies, self ownership, individual/family investors, banks, foundations/research institutes, government, unnamed private shareholders and 
other unnamed shareholders. Bankscope Fitch IBCA also provides for listed banks data on the percentage of stocks held by the public. We use a sample consisting of an unbalanced panel of annual report data from 1999 to 2005 for a set of European commercial banks established in 16 Western European countries: Austria, Belgium, Denmark, Finland, France, Germany, Greece, Ireland, Italy, Luxembourg, Netherlands, Portugal, Spain, Sweden, Switzerland and United-Kingdom² ${ }^{2}$ As argued above, we do not consider other types of banks (cooperative, mutual...) to ensure that all the banks in our sample follow the same profit maximization objective (homogeneous objective function). We identify in Bankscope 1586 commercial banks for which income statements and balance sheets are provided for the period 1999$2005^{3}$. We delete all the banks with less than five consecutive years of time series observations ${ }^{4}$, which leaves us with 688 banks. Out of this number of banks, we isolate 320 banks for which detailed data on direct ownership are available for the years 2001, 2003 and 2005 in the annual financial statement ${ }^{5}$. Eventually, we apply other selection criteria and end up with a smaller sample of banks. First, we only consider banks with a stable ownership structure by comparing the proportion of equity held by the main shareholders over the period 1999-2005. This restriction is important to accurately analyze the impact of ownership structure on the performance and risk of banks. Since our aim is to focus on the influence of different categories of shareholders on management, we need to exclude short run ownership and hit and run strategies that will not shape the behavior of management and therefore bank risk/profitability in a given direction. We hence only keep banks for which the ownership shares of the main category of shareholders fluctuate by less than $10 \%$ over the considered period. 249 banks are consistent with this criterion which enables us to work on a firm-level homogeneous sample. The final sample consists of 249

\footnotetext{
${ }^{2}$ Norway is excluded from our analysis because no banks provide data consistent with the criteria we use to build and clean our database.

${ }^{3}$ All the banks in our sample publish their annual financial statements at the end of the calendar year. We consider local Generally Accepted Accounting Principles (GAAP) for all our sample period.

${ }^{4}$ This condition enables us to accurately compute the standard deviations of some variables to define risk indicators.

${ }^{5}$ Each annual financial statement provides information on the ownership structure of banks for the current year and the previous two years. The report of the year 2001 therefore gives information on the ownership structure of the years 1999, 2000 and 2001. In our study, we consider the direct owner that can be different from the ultimate owner (for example $20 \%$ of a bank's stocks can be owned by a firm (direct owner) in which a family might have a stake of $10 \% \ldots$... We use direct ownership in order to consider the different categories that directly exert control. We do not consider the ultimate owners because Bankscope only provides information on such owners since 2004 and only for shareholders with stakes higher than $25 \%$.
} 
European commercial banks within which 80 are listed publicly traded banks ${ }^{6}$ (see Table 1 for further details on the distribution of banks by country). Among these banks, 191 banks have a major shareholder with a stake above 50\% throughout the whole sample period and 58 banks (out of which 44 are listed) exhibit ownership shares by the main shareholder fluctuating by less than $10 \%$. We also consider a subsample that satisfies the criteria that the sum of the different shares that are displayed in Bankscope is at least equal to $99 \%{ }^{7}$. This criterion leaves us with 198 banks, within which 29 are listed. We test the robustness of our results by running our estimations on both the large sample of 249 banks and on the restricted sample of 198 banks. We also conduct estimations on the sample of 191 banks for which we have a major shareholder with a stake above $50 \%$ to be consistent with previous studies.

Insert Table 1 here

Table 2 presents some descriptive statistics for both our sample of 249 banks and the largest sample of 1586 commercial banks available under Bankscope Fitch IBCA for our period of analysis. We use data from consolidated accounts if available and from unconsolidated accounts otherwise.

Insert Table 2 here

\subsection{Risk variables}

We consider different measures of asset risk and default risk commonly used in the literature. We compute three standard measures of risk for each bank throughout the period under study based on annual accounting data: the standard deviation of the return on average assets (SDROA), the standard deviation of the return on average equity $(S D R O E)^{8}$, and the mean of the ratio of loan loss provisions to net loans $\left(M_{-} L L P\right)$. We also compute default risk measures. First we use the " $\mathrm{Z}$ score" proposed by Boyd and Graham (1986) which indicates the probability of

\footnotetext{
${ }^{6}$ Our full dataset contains 137 listed banks. We need to delete: (i) 7 banks with less than five years of time series observations; (ii) 31 banks for which ownership is not detailed in the three reports provided for the years 2001, 2003 and 2005; (iii) 19 banks that exhibit a change in ownership structure between 1999 and 2005.

${ }^{7}$ The data on ownership structure provided by Bankscope (\% share of each type of owner) do not always add up to $100 \%$, particularly for listed banks because we do not always have the percentage held by the public.

${ }^{8}$ We define average equity and average assets at time $\mathrm{t}$ as: (amount outstanding at time $\mathrm{t}+$ amount outstanding at time $\mathrm{t}-1) / 2$.
} 
failure of a given bank $(Z)^{9}$. Higher values of Z-scores imply lower probabilities of failure. Second, we use the ZP Score $(Z P)$ as in Goyeau and Tarazi (1992) and Lepetit et al. (2008) and its two additive components ${ }^{10}$ (ZP1 and ZP2). ZP1 is a measure of bank portfolio risk whereas $Z P 2$ is a measure of leverage risk.

Table 2 provides statistics for some of our measures of asset risk and default risk, on average for the whole sample of banks, and for the panel of non-listed and listed banks. Mean tests show that we do not have significant differences in risk between our two samples of publicly-owned and privately-owned banks. These results are consistent with Kwan (2004) who works on a panel of US banks. However, unlike his findings our sample of European public banks exhibits, on average, a higher profitability than our sample of European private banks. A higher profitability for listed banks could be explained by the fact that such banks can raise additional equity capital at lower transaction costs, which enables them to generate faster growth in equity and assets and ultimately to become larger. These banks might benefit from economies of scale and generate higher profit per unit of risk than private banks.

\subsection{Ownership variables}

In our study, we code the ownership structure based on the stockholder information contained in the BankScope database. As our aim is to analyze how the interaction of equity held by different types of shareholders influences the risk-taking behavior of banks, we have to consider as many categories of owners as we can. However, we only keep the categories of owners for which we are able to identify their nature, behavior and incentives to take risk. We therefore exclude three categories of owners provided by BankScope: public, unnamed private shareholders and other unnamed shareholders. We also require each category of owner to hold equity in at least five banks. These criteria lead us to exclude three categories of owners, which are self owned, foundation and government ${ }^{11}$.

Consequently, we end up with five categories of owners that are considered in our study: (i) managers/directors (MANAGER); (ii) non-financial companies (COMPANY); (iii) individual/family investors (FAMILY); (iv) banks (BANK); and (v)

\footnotetext{
${ }^{9} \mathrm{Z}=(100+$ average ROE $) /$ SDROE, where ROE and SDROE are expressed in percentage.

${ }^{10} \mathrm{ZP}=\mathrm{ZP}_{1}+\mathrm{ZP}_{2}=\frac{\text { average ROA }}{\text { SDROA }}+\frac{\text { average (Total equities / Totalassets) }}{\text { SDROA }}$.

${ }^{11}$ Few European banks have equity held by governments, and those that do are mostly German cooperative banks which we do not consider in our sample.
} 
institutional investors - insurance company, financial companies and mutual \& pension funds - (INSTITUT). We create five variables which report for each bank in our sample the proportion of equity held by each category of owner. This approach allows us to measure the dispersion of ownership and also to analyze the influence of different combinations of shareholders on bank risk and profitability. It also enables us to account for possible coalitions among different categories of shareholders.

Table A1 in the appendix gives, per country, the distribution of banks for which the ownership variables are different from zero as well as the average percentage of stock held by the different categories of owners. Tables 3, 4 and 5 provide some statistics about the ownership structure of our 249 sample banks. Table 3 shows that the major category of shareholders, in our sample of 249 European commercial banks, are other banking institutions with an average of $81.52 \%$ of equity. Banks that hold equity in another bank exhibit on average higher stakes in non-listed banks than in listed banks. Non-financial companies and institutional investors are also strongly involved in our sample banks as they hold equity in respectively 78 and 55 banks out of the 249 banks of our sample. Non-financial companies hold on average a higher percentage of equity (39.48\%) than institutional investors (35.40\%). A closer look shows that non-financial companies and institutional investors are more often involved in listed banks but they hold a higher proportion of total equity in nonlisted banks. Individuals/families are involved in a relatively few number of listed and non-listed banks (25 banks) ; they are more often involved in listed banks but they hold a higher proportion of equity in privately-owned banks $(50.39 \%)$ than in publicly-held banks (5.87\%). The category managers/directors holds equity in only 8 banks out of which 7 are listed banks and the average proportion of stocks they hold is very low $(9.51 \%)$ compared to the other types of owners.

Table 4 displays the distribution of our sample of non-listed and listed banks according to the percentage of equity held by each category of shareholder. The proportion of equity of each category of owner (except managers/directors) are well distributed in the interval ]0-100]. In Table 5, we also present the mean of each risk and default indicator for each of our five categories of owners according to the proportion of equity they hold. Table 5 shows strong heterogeneity among different types of shareholders, allowing us to analyze the behavior of banks depending on their ownership structure. 
We also compare asset risk, default risk, profitability and asset growth of public and private banks when held by the same main category of shareholders ${ }^{12}$ (see Figure 1). While Figure 1 shows differences in asset risk and profitability between listed and non-listed banks for a given shareholder type, these differences are not statistically significant. Interestingly, however, we find that public banks exhibit higher average asset growth rate than private banks, regardless of the category of the main shareholder. These results suggest that, as discussed above, public banks might actually choose to raise equity more easily and at lower cost to generate faster growth.

Insert Tables 3, 4 and 5 and Figure 1 here

We further measure the ownership dispersion/concentration of our sample of European commercials banks in order to analyze its possible impact on the risk-taking behavior of banks. The effects of ownership concentration on firm performance are theoretically complex and empirically ambiguous. Several approaches have been proposed to explain the ambiguity of the relationship between ownership concentration and firm performance. Shleifer and Vishny (1986) and Aghion and Tirole (1997) show that a concentrated ownership might improve the performance of firms by increasing monitoring and alleviating the free-rider problem in takeovers. But other theoretical works show that large shareholders might exercise control rights in order to create private benefits and sometimes to expropriate smaller investors (Shleifer and Vishny, 1997). Another potential cost of concentration may result if managerial initiative is repressed by excessive monitoring (Burkart et al., 1997).

Our data provide the proportions of total equity held by different categories of owners but not the stakes held by each investor at the individual level. We therefore need to check if the level of ownership dispersion within each of the five categories of shareholders we consider matters or not when assessing the relationship between ownership structure and bank risk/profitability. For this purpose we measure ownership dispersion/concentration by computing a Herfindahl index for each of our five categories of shareholders ${ }^{13}$ (HERF_MANAGER, HERF_FAMILY,

\footnotetext{
${ }^{12}$ The main category of shareholders is defined as the one with the highest level of equity holding.

${ }^{13}$ For example, for the category INSTITUT, we compute for each bank $i$ the variable $\mathrm{OS}_{\mathrm{j}}$ defined by the ratio of the percentage of equity held by each institutional investor $j$ to the total percentage of equity held by all the institutional investors. We then compute our Herfindahl index as $\sum_{j=1}^{n} O S_{j}^{2}(j$ represents
} 
HERF_INSTITUT, HERF_COMPANY and HERF_BANK). Table 6 highlights that, on average, ownership is relatively well concentrated for all the categories of shareholders. This is consistent with the studies of La Porta et al. (1999) and Becht and Roell (1999) who highlight that ownership structure of firms across the world present a relatively high degree of ownership concentration. Tables 6 and 7 show that the category MANAGER presents the highest level of ownership concentration with a Herfindahl index of 0.948 and on average 1.12 shareholders per bank. The category $B A N K$ also exhibits a relatively high level of ownership concentration followed by FAMILY and INSTITUT. The category with the highest number of shareholders per bank is COMPANY, with an average of 4.25 shareholders and a maximum of 66 shareholders involved in the same bank.

Table 8 shows no significant differences in terms of risk and profitability between banks with a relatively high level of concentration for the categories of FAMILY, INSTITUT and COMPANY and those with a relatively low level of ownership concentration in these categories. At first sight, there seems to be no impact of ownership concentration/dispersion on the risk-taking behavior of banks. When banks hold equity in other banks and their stakes are very concentrated, we find that asset risk and profitability are significantly higher compared to banks with a more dispersed bank ownership.

Insert Tables 6, 7 and 8 here

Finally, we compare our sample of commercial banks with the larger population of European commercial banks contained in Bankscope by looking at possible differences between the importance of each category of owner in our sample of 249 banks and those of the largest sample of 905 banks for which Bankscope Fitch IBCA provides information on the ownership structure in 2005. The frequencies of banks for which each category of owner holds a positive percentage of equity in our sample (see Table 3) are not significantly different from those of the largest sample of 905 banks (see Table A2 in appendix) ${ }^{14}$. However, the average percentage of equity

\footnotetext{
the category of shareholders INSTITUT and $n$ the total number of institutional investors that hold equity in the bank $i$ ). For example if we have for bank $i$ two institutional investors holding $10 \%$ of total equity and $45 \%$ of total equity, our Herfindahl index will take the value of 0.70 , indicating a relatively high level of concentration for the category INSTITUT.

${ }^{14}$ The mean tests performed are available from the authors on request.
} 
held by the five categories of owners that we consider is higher in our sample of 249 banks than in the larger sample of 905 banks. This difference could be explained by our choice to restrict our analysis to banks with a stable ownership structure throughout our sample period. Investors who hold a stable stake in financial firms might be more strongly involved in equity than investors with more diversified portfolios and/or shorter investment horizons.

\section{Method and hypotheses tested}

Our objective is first to analyze if commercial banks with different ownership structures present significant differences in risk and profitability. Second, we also investigate whether market discipline can influence the relationship between ownership structure and risk. We therefore test two hypotheses by considering two specifications.

Hypothesis 1: Different ownership structures imply different levels of risk and profitability.

We use the following econometric model to test hypothesis 1 :

\section{Model 1}

$$
\begin{aligned}
Y_{i}=\alpha_{0}+ & \alpha_{1} \text { MANAGER }_{i}+\alpha_{2} \text { FAMILY }_{i}+\alpha_{3} \text { COMPANY }_{i}+\alpha_{4} \text { BANK }_{i}+\alpha_{5} \text { LISTED }_{i} \\
& +\alpha_{6} \text { M_LNTA }_{i}+\alpha_{7} \text { M_OEQUITY }_{i}+\alpha_{8} \text { M_DEPOSIT }_{i}+\alpha_{9} \text { LAMBDA }_{i} \\
& +\alpha_{10} \text { LAMBDA*LISTED }_{\mathrm{i}}+\gamma_{\mathrm{j}} \sum_{\mathrm{j}=1}^{15} \text { COUNTRY }_{\mathrm{j}}+\varepsilon_{\mathrm{i}}
\end{aligned}
$$

where: $Y_{i}$ is either a measure of asset risk (SDROA, SDROE and M_LLP), default risk (Z, ZP, ZP1 and ZP2) or a measure of profitability (the mean of the return on average assets $-M \_R O A$ - and the mean of the return on average equity - $\left.M \_R O E-\right)^{15}$; MANAGER, FAMILY, COMPANY and BANK represent the percentage of stock held respectively by managers/directors, families/individuals, non-financial companies, and banks; LISTED is a dummy variable which takes the value of one if the bank is listed on the stock market and zero otherwise; M_LNTA is the mean of the natural logarithm of total assets; M_OEQUITY is the mean of the ratio of equity to total assets

\footnotetext{
${ }^{15}$ We do not include an independent variable reflecting asset risk when we consider profitability as the dependent variable because we have a high degree of colinearity between our ownership variables and asset risk.
} 
orthogonalized with TA; M_DEPOSIT is the mean of the ratio of deposits to total assets; $L A M B D A$ is the inverse Mills ratio estimated for each bank from the first-stage Probit model; COUNTRY is a country dummy variable.

We consider five categories of owners that may influence the risk-taking behavior of banks (MANAGER, FAMILY, COMPANY, BANK and INSTITUT). In our specification, we remove INSTITUT from Model 1 in order to use institutional investors as a benchmark ownership share. The theoretical link between risk and institutional ownership is the most settled. As institutional investors hold shares in sufficiently diversified investment portfolios, they are assumed to favor all positive net present value investments at the individual bank level. As shareholders, institutional investors are indifferent to the riskiness of an investment in a specific bank and are only concerned about expected return. By removing INSTITUT from our set of independent variables, we are able to analyze, with Model 1, if a shift in ownership from institutional investors to another category of owners results in an increase or a decrease in risk and profitability (see Appendix 2 for details). The excluded shareholder group INSTITUT is the benchmark against which the signs and the magnitudes of the coefficients on the four other ownership shares are evaluated.

The theory regarding the attitude of individuals and families toward risk stipulates that their portfolio is less diversified than those of other shareholders, particularly institutional investors, and they therefore have incentives to take less risk because if the bank fails they lose more compared to other shareholders. We therefore expect that a shift in equity from institutional investors (INSTITUT) to individuals/families (FAMILY) implies a decrease in $\operatorname{risk}^{16}\left(\alpha_{2}\right.$ negative).

Previous studies that analyzed the incentives of managers/directors to take risk were mostly dedicated to US firms. Most studies have shown that when a manager/director holds a small share of the bank's equity, she/he may have incentives to take less risk. If the bank fails, she/he loses both her reputation and human capital investment. Our MANAGER variable is very close to the proxy used by Saunders et al. (1990) which is computed as the number of shares held by executive and directors divided by the total number of shares outstanding. Note that the underlying

\footnotetext{
${ }^{16}$ We give here the expected sign for the measures of asset risk (SDROA, SDROE and M_LLP). We expect the opposite sign for the default risk measures $(Z$ and $Z P)$ as a lower $Z$-score value implies a higher probability of failure.
} 
assumption in the literature is that a low proportion of stocks held by managers is associated with a low share of the bank's stocks in the managers' non-human wealth. Also, a higher proportion of stocks held by managers is assumed to align their interest with those of shareholders as long as the larger investment in the bank's stocks does not prevent them from holding diversified portfolios. In our study, we do not have information about managers' wealth and the level of diversification of their investment portfolio. We assume that the portfolio of managers is less diversified than those of our benchmark, institutional investors. We therefore expect a negative coefficient for the variable MANAGER ( $\alpha_{1}$ negative).

We also consider shares held by non-financial companies (COMPANY). Banks with a large portion of stocks held by firms are prone to increase the riskiness of loans granted to owners. Moreover, if a bank is behind an industrial group, the group management will have incentives to manipulate the bank to maximize the wealth of ultimate owners. Therefore, banks that are controlled by firms might have incentives to encourage riskier strategies than other categories such as families and individuals. Also, it could be argued that non-financial companies might hold sufficiently diversified asset portfolios just like institutional investors. If this is the case, their risk incentives could be aligned with those of institutional investors. However our data do not provide information on the structure of their investment portfolios. The impact on bank risk of a shift in equity from institutional investors to non-financial companies is therefore undetermined ( $\alpha_{3}$ non significant or positive/negative).

The fourth category of shareholders is represented by banks $(B A N K)$. As we can see in Tables 3 and 4, banks hold important stakes in other banks. When a bank owns another bank, the important risk-return relationship and strategies are expected to be at the parent company, and not at its subsidiary firm. However, banks as a shareholder might encourage relatively conservative risk-taking strategies at the individual bank level for both safety net reasons and reputation concerns. In the event of financial distress or failure, the parent bank is expected to support its subsidiary which can be costly. We expect a negative coefficient for the variable $B A N K\left(\alpha_{4}\right.$ negative).

Control variables are introduced to account for size differences (natural logarithm of total assets $M_{-} L N T A$ ), business differences (deposits to total assets 
$M_{-} D E P$ ) and leverage differences (equity to total assets $M_{-} E Q U I T Y$ ). Alternative control variables (the ratio of loans to total assets and the ratio of net non-interest income to net operating income), are also introduced to check for robustness. Because $M \_L N T A$ and $M \_E Q U I T Y$ are highly correlated, the leverage ratio is orthogonalized with total assets (M_OEQUITY). As the information on the ownership structure of our sample of banks is invariant through time (1999-2005 period) and as our measure of asset risk and default risk are computed using the standard deviations of ROA and ROE, we conduct cross-section regressions. We therefore compute the means of our three control variables over the whole sample period. We also control for possible country specific effects by including country dummies (COUNTRY).

We further check if publicly-held banks behave differently compared to privately-owned banks, by including in Model 1 a dummy variable, LISTED, which takes the value of one if the bank is listed on the stock market and zero otherwise. This dummy variable is expected to capture differences in risk and profitability for listed and non-listed banks. Market exposure is expected to influence the behavior of publicly-held firms. However, the effect of market exposure on risk is unclear. On the one hand, market discipline should impose strong incentives on banks to conduct their business in a safe, sound and efficient manner, including an incentive to maintain a high level of equity capital to face potential future losses. On the other hand, publiclyheld banks can have access to additional equity at a lower cost than privately-owned banks. Public banks might consequently have a greater ability to become larger and make acquisitions. They also have a higher degree of freedom to manage their equity and meet the regulatory capital requirement, which gives them more flexibility to invest in risky projects with a higher expected return. Market forces might therefore impose a higher risk-adjusted return for public banks. The expected sign associated to the variable LISTED is therefore undetermined $\left(\alpha_{5}\right.$ non significant or positive/negative).

We might potentially have two endogeneity problems in our regressions, one with our ownership variables, which are continuous, and another one with the binary variable LISTED. We deal with these two problems separately.

Some studies (Demsetz and Lehn, 1985; Himmelberg et al., 1999, Gugler and Weigland, 2003) raise the problem that ownership might be endogenous as it might be influenced by the level of performance and risk of the firm. In our study, it can be 
argued that investors can be attracted by banks with different risk levels. Some investors might simply choose to invest in banks with higher risk profiles in order to maximize their utility. We test for the presence of an endogeneity bias in the estimated equation for the three ownership variables for which we might encounter such a problem (COMPANY, BANK and INSTITUT) by using the Hausman test. We consider several instrumental variables related to the legal environment of the banking system and to the nature of the bank's activities ${ }^{17}$. We verify that for each of our ownership variables, we have at least one instrument which is not weak. The Hausman tests show that the endogeneity problem is not a major issue ${ }^{18}$, which implies that OLS should be an efficient estimator.

The choice for a bank to become public or remain private also raises potential endogeneity issues in our econometric specification. Indeed, banks will make their choice to become listed on a stock market or remain private on the basis of the expected future changes in growth and profitability. We account for a possible endogeneity of the choice to be public or private by using the Heckman (1979) twostage approach as in Givoly et al. (2007) and Nichols et al. (2009). In a first stage, we use a Probit model to determine the variables that influence the choice of the bank to be publicly or privately owned. We then use the estimates of the Probit model to compute the inverse Mills ratio for each sample bank $(L A M B D A)^{19}$. In the second stage, we introduce the inverse Mills ratio as a control variable in Model 1. By including $L A M B D A$ in Model 1, we control for the correlation between LISTED and the second stage errors to obtain consistent coefficient estimates. We also introduce

\footnotetext{
${ }^{17}$ We consider several instrumental variables. First, we differentiate the banking systems according to their legal environment. We use the database of La Porta et al. (1998) which groups the countries into four general legal families: English common law origin; countries of French civil law origin; countries of German civil law origin; and countries of Scandinavian civil law origin. Second, we classify the banks of our sample according to the nature of their activities (proportion of subsidiaries abroad, focus or diversification, extent of loan activities in the balance sheet, ...). The strategies pursued by banks will not change much over time and might influence the choice of shareholders.

${ }^{18}$ The Hausman tests show that the null hypothesis of exogeneity is not rejected for INSTITUT (except for SDROA and Z), COMPANY (except for SDROA) and BANK (except for ZP1 and ROE).

${ }^{19}$ We use mean tests to compare balance sheet and income statement characteristics between listed and non-listed banks (as in Table 2). We retain 11 ratios out of the 24 initially examined ratios which are significantly different between listed and non-listed banks: consumer loans/total assets, total earning assets/total assets, total deposits/total assets, cash/total assets, ROA, liquid assets/total assets, net loans/total assets, asset growth rate, market funding/total assets, equity/total assets. These variables are used to model the selection of public versus private status. The results from the Probit model are available from the authors on request. The Pseudo R-square statistic indicates that the model explains almost $68 \%$ of the cross-sectional variation in the choice of public-private status within our sample.
} 
an interaction variable combining $L I S T E D$ and $L A M B D A$ to allow the coefficient to vary between listed and non-listed banks.

The second objective of our paper is to further investigate the issue of market discipline. We test the extent to which market forces influence the behavior of public banks under different ownership structures. As discussed above, two different effects can be expected from market discipline on the behavior of public banks: $(i)$ a decrease in risk if market forces moderate the incentives of banks dominated by institutional investors or other shareholder categories rationally inclined to take higher risks; (ii) an increase in risk if market forces align the objectives of public banks to generate faster growth and to obtain a higher risk-adjusted return. As market forces might line-up the objective of listed banks, we expect that their ownership structure will no more affect their risk level. These two opposite effects of market forces on the risk behavior of public banks lead us to test the two following alternative hypotheses:

Hypothesis 2a: Market discipline can mitigate risk in public banks that are owned or controlled by shareholder categories that would otherwise be inclined to take higher risk in a private bank.

Hypothesis 2b: Different ownership structures do not imply different levels of risk and profitability for publicly-held banks.

For this purpose, we estimate an augmented model that captures the interaction between the different categories of owners ${ }^{20}$ (FAMILY, COMPANY, BANK and INSTITUT) and the dummy variable LISTED which indicates if a bank is listed or not. We therefore use the following model to test the alternative hypotheses $2 \mathrm{a}$ and $2 \mathrm{~b}$ :

\section{Model 2}

$$
\begin{aligned}
& \mathrm{Y}_{\mathrm{i}}=\beta_{0}+\beta_{1} \text { FAMILY }_{\mathrm{i}}+\beta_{2} \text { COMPANY }_{\mathrm{i}}+\beta_{3} \text { BANK }_{\mathrm{i}}+\beta_{4} \text { FAMILY* }^{*} \text { LISTED }_{\mathrm{i}} \\
& +\beta_{5} \text { COMPANY }^{*} \text { LISTED }_{\mathrm{i}}+\beta_{6} \text { BANK }^{*} \text { LISTED }_{\mathrm{i}}+\beta_{7} \text { M_LNTA }_{\mathrm{i}}+\beta_{8} \text { M_OEQUITY }_{\mathrm{i}} \\
& +\beta_{9} \text { M_DEPOSIT }_{\mathrm{i}}+\beta_{10} \text { LISTED }_{-} \beta_{11} \text { LAMBDA }_{\mathrm{i}}+\beta_{12} \text { LAMBDA*LISTED }_{\mathrm{i}} \\
& +\gamma_{\mathrm{j}} \sum_{\mathrm{j}=1}^{15} \operatorname{COUNTRY}_{\mathrm{j}}+\varepsilon_{\mathrm{i}}
\end{aligned}
$$

\footnotetext{
${ }^{20}$ As managers hold stocks in only one non-listed bank, we cannot consider the variable MANAGER in Model 2.
} 
As in Model 1, we use INSTITUT as a benchmark. Again, as we remove INSTITUT from the set of independent variables, the estimated coefficient of each interaction variable refers to a substitution between each ownership component and the INSTITUT component (see Appendix 2 for details).

Interaction variables measure the impact of market exposure on the relationship between the proportion of equity held by each category of owner and the dependent variable. A negative and significant value of the sum of the coefficients of the variable COMPANY and the interaction variable COMPANY*LISTED $\left(\beta_{2}+\beta_{5}<0\right)$ will indicate that a shift in equity from institutional investors to nonfinancial companies is associated with a decrease in risk for listed banks. Such a result will be consistent with our hypothesis $2 \mathrm{a}$. If the sum of these two coefficients is not significantly different from zero, then our model will highlight that a change in the ownership structure of listed banks will not affect their risk level, which is consistent with hypothesis $2 b$.

\section{Results}

Tables 9 and 10 show the results obtained for Models 1 and 2. Because, as discussed above, we do not face strong endogeneity issues, we use OLS estimation techniques with the Heckman correction ${ }^{21}$. We also correct for heteroskedasticity following White's methodology. As we remove the ownership component "institutional investors" from Models 1 and 2, the estimated coefficient associated to each ownership component has to be interpreted as the effect of a substitution between this component and the INSTITUT component (see Appendix 2 for details).

Our results are consistent with hypothesis 1 . We find that the portion of total equity held by different categories of shareholders is significant in explaining risk and profitability differences (see Table 9).

First, as expected, our results show that higher portions of total stock held by individuals/families (compensated in our approach by a decrease in the INSTITUT component) are associated with lower asset risk and credit risk. But, interestingly, we also find that a shift in equity from institutional investors to individuals/families is not significantly associated with a decrease in profitability. As argued above, such

\footnotetext{
${ }^{21}$ We also estimate Models 1 and 2 without the Heckman correction when the inverse Mills ratio $(L A M B D A)$ is not significant. The results regarding our variables of interest are unchanged.
} 
shareholders hold less diversified portfolios than institutional investors and are often involved in the management of such banks. Regarding our default risk measures, the results show that a higher stake of individuals/families is associated with a lower probability of default $(Z)$.

Second, we find that the coefficients associated to the variable $B A N K$ are not significant when the dependent variables are asset risk measures (SDROA and $S D R O E)$ or profitability measures (ROA and $R O E)$. These results indicate that a shift in equity from institutional investors to banks does not imply a different level of asset risk and profitability. Also, we find a negative and significant relationship at the ten percent level between the $B A N K$ ownership component and the credit risk measure $\left(M \_L L P\right)$. This result might support the hypothesis that, as shareholders, banking institutions encourage relatively conservative risk-taking strategies but only for traditional lending activities. In addition, our results show that default risk $(Z)$ is lower when the portion of shares held by such banking institutions increases.

Third, we do not find any significant coefficient associated to the variable $C O M P A N Y$. A shift in equity from institutional investors to non-financial companies does not imply a change in asset risk, default risk and profitability. Such a result suggests that institutional investors and non-financial companies might have similar risk-return objectives.

Lastly, we find a significant and negative relationship between the variable $M A N A G E R$ and our credit risk measure $\left(M_{-} L L P\right)$. A shift in ownership from institutional investors to managers is associated to a lower level of credit risk but our results also highlight a higher probability of default $(Z)$. Meanwhile, we find that a higher involvement of managers in equity has a positive impact on profitability. However, it should be noted that our data do not allow us to infer any accurate relationship between manager involvement and risk. As shown in Table 3 and Table A2, managers rarely hold stocks in their own company in our sample. Moreover, 7 out of the 8 banks in which they have a stake are listed banks.

Regarding the influence of market forces on bank performance, the coefficient associated to the variable LISTED in Model 1 is not significant. At first sight, there seems to be no significant difference in risk and profitability between listed and non listed banks suggesting that market forces might not strongly influence the risk behavior of listed banks in a specific way. 
We further investigate the issue of market discipline with Model 2 by considering the interaction between the portion of equity held by each category of owner and the exposure of banks to market forces (see Table 10) ${ }^{22}$.

First, for non-listed banks, we find a negative and significant relationship between FAMILY and two of our risk measures (SDROE and M_LLP). Therefore, the above result indicating lower asset risk when families/individuals hold a higher proportion of stocks (compensated by a decrease in INSTITUT) holds for non-listed banks.

Second, our results highlight that, for listed banks, a shift in equity from institutional investors to non-financial companies or individuals/families does not imply a change in asset risk, default risk and profitability (except for SDROA for FAMILY, but only at the $7.64 \%$ level). These results are consistent with hypothesis $2 \mathrm{~b}$ that changes in the ownership structure of listed banks do not lead to changes in risk. Meanwhile, our results show that a decrease in the proportion of equity held by institutional investors, offset by an increase in equity held by banks, implies a lower credit risk and probability of default, but only for listed banks. Market forces might therefore moderate the risk taking of banks with higher stakes by banking institutions when they are listed.

Insert Table 10 here

On the whole, our analysis shows that different ownership structures imply different levels of bank risk, which is consistent with hypothesis 1 . We find that a higher involvement of either individuals/families or banking institutions implies a decrease in asset risk and default risk, which is not offset by lower profitability. Our results also show that a shift in equity from institutional investors to non-financial companies does not involve any changes in asset risk, default risk and profitability suggesting identical risk-return preferences of both categories of shareholders. When we further take into account the impact of market exposure, we find that changes in the ownership structure of publicly-held banks do not strongly affect risk. However,

\footnotetext{
${ }^{22}$ We do not include MANAGER in Model 2 because, in our sample, only one bank involving managerial shareholding is not listed (see Table 3).
} 
to some extent, credit risk and default risk are lower in listed banks when equity stakes are transferred from institutional investors to banking institutions.

\section{Deeper investigation and robustness checks ${ }^{23}$}

In order to further examine issues related to the influence of ownership structure on the risk-taking behavior of banks, we carry out a deeper investigation of our sample.

\section{Ownership Dispersion/Concentration within each category of shareholders}

We account for ownership dispersion/concentration. We estimate the impact of the dispersion/concentration of ownership by augmenting Model 1 with interaction variables involving the different categories of owners (MANAGER, FAMILY, INSTITUT, COMPANY and BANK) and their respective Herfindahl index (HERF_MANAGER, HERF_FAMILY, HERF_INSTITUT, HERF_COMPANY and HERF_BANK). The results are presented in Table A3. Our results show that the degree of ownership concentration of families/individuals, industrial companies and banking institutions does not influence the relationship between ownership changes and the risk-taking behavior of banks. We also run our estimations on the two subsamples of non-listed and listed banks ${ }^{24}$. Our results show that ownership concentration does not matter in the relationship between ownership structure and bank risk for both listed and non-listed banks. We only find, for non-listed banks, that a higher involvement of families/individuals associated to a higher ownership concentration implies a decrease in asset risk, but no change in profitability.

\section{Size effect}

We also conduct our estimations separately for large banks (total assets $>1$ billion Euros) and small banks (total assets $<1$ billion Euros) to further check for size effects on the relationship between ownership structure and banks' behavior in terms of risk taking. Tables A4 and A5 in the appendix present the results obtained for

\footnotetext{
${ }^{23}$ Some of the estimation results discussed in this section are not presented in the paper but are available from the authors on request.

${ }^{24}$ We do not include MANAGER in these estimations because there is only one non-listed bank in which managers/directors hold equity.
} 
Model $1^{25}$. Shifts in equity are significant in explaining risk differences for both samples of large and small banks. A shift in equity from institutional investors to individuals/families implies lower asset risk and lower default risk for both small and large banks. Moreover, a higher involvement of individuals/families in small banks leads to a higher level of profitability suggesting higher efficiency in management. Also, our results show that a shift in equity from institutional investors to nonfinancial companies does not involve a change in asset risk, profitability and default risk for large banks, whereas it implies a decrease in asset risk for small banks.

\section{Reliance on market debt}

We further test the impact of market exposure on the risk-taking behavior of banks under different ownership structure profiles by using another proxy. We consider that a bank heavily reliant on market debt is likely to be influenced by market forces even if it is not listed on a stock market. We therefore construct a dummy variable based on the ratio of market debt plus uninsured deposits to total assets. We consider that banks with a ratio higher than the median of the sample can be effectively disciplined by the market. We run our Model 2 by using this dummy variable to construct the interaction variables (see Table A6 in appendix). We find that a shift in equity from institutional investors to individual/families implies lower asset and default risk for banks which have a relatively low ratio of market debt. Our results also show that changes in the ownership structure of banks which are strongly reliant on market debt do not affect asset and default risk. These results are consistent with our hypothesis that market forces align the risk-taking behavior of banks.

\section{Nature of main shareholder}

Finally, to be consistent with previous studies on ownership in banking, we also classify banks according to the nature of their main category of shareholders. The objective of using such a classification is to analyze if the risk-taking behavior of banks is different according to the nature of the main category of shareholders. We run a differently specified regression on our subsample of 191 banks in which the major shareholder holds more than $50 \%$ of total equity. We have in our sample of 249 banks: (i) 0 manager-owned bank; (ii) 4 family and individual-owned banks; (iii) 14

\footnotetext{
${ }^{25}$ The distribution of banks according to the percentage of equity held by each category of shareholder does not allow us to accurately run Model 2 for the sub-samples of small and large banks.
} 
institutional investor-owned banks; (iv) 22 company-owned banks, and (v) 126 bankowned banks (see Table 4). We create the following four dummy variables which take the value of one when ownership is higher than $50 \%$ of total equity and 0 otherwise: FAMILY_OWNED, INSTITUT_OWNED, COMPANY_OWNED and BANK_OWNED. We do not consider manager-owned banks in our estimations because no banks have a majority of equity held by this category of shareholders (see Table 4). Table A7 in the appendix shows the results of the estimations ${ }^{26}$. Our results show that banks which are majority-owned by families/individuals exhibit a lower asset risk level (SDROE and $\left.M \_L L P\right)$ but not a lower profitability. We also find that banks which are majorityowned by other banking institutions exhibit a lower credit risk.

In addition, we also estimate the same model by considering that there is a majority ownership when a category of owner holds a percentage of total equity strictly above $33 \%$. Our findings are unaltered for the variables of interest. Our results therefore highlight that both the degree of involvement of shareholders and the nature of the main category of shareholders influence the attitude of banks toward risk.

\section{Robustness checks}

Several robustness checks are also performed. First, we estimate Model 1 and Model 2 using the restricted sample of 198 banks for which the sum of the different equity components is at least equal to $99 \%$. We consider this restricted sample to ensure that our results are not biased by the fact that some information regarding ownership structure might be missing or not reported in the Bankscope dataset that we use. We also estimate Models 1 and 2 on a subsample from which we exclude observations with a value of zero for the proportion of equity held by institutional investors. Our conclusions remain unchanged.

Second, we estimate Model 1 on the two sub-samples of privately-owned and publicly-held banks. Our results regarding our ownership variables are unchanged. We find that a shift in equity from institutional investors to individuals/families implies a decrease in asset risk and default risk whereas a higher involvement of nonfinancial companies does not imply any changes in risk and profitability. For listed banks, our results show that bank ownership structure changes do not affect risk

\footnotetext{
${ }^{26}$ The limited number of banks for which we have a majority owner and our specific regression specification which is reliant on dummy variables do not allow us to introduce interaction variables as in Model 2.
} 
taking, except that risk is lower when equity stakes are transferred from institutional investors to banking institutions.

Third, we also run separate regressions introducing our ownership variables one by one along with the control variables. We find that a higher involvement of institutional investors implies a higher probability of default for both listed and nonlisted banks. Our results also show that a higher involvement of individuals/families implies a lower asset risk, but only for non-listed banks. A higher proportion of equity held by either non-financial companies or banking institutions does not affect risk taking, both for privately-owned and publicly-held banks.

Fourth, we also perform a number of robustness checks that are specification related. Other control variables to account for business differences are introduced in the estimations such as the ratio of loans to total assets and the ratio of net noninterest income to net operating income. Our conclusions regarding the inclusion of the ownership variables remain unchanged.

\section{Summary and concluding remarks}

The objective of this study is to analyze if different ownership structures are associated with different levels of risk and profitability in both privately owned and publicly held banks. We differentiate five categories of shareholders that are assumed to have different risk-taking incentives (managers/directors, institutional investors, non-financial companies, individuals/families, and banks). We use the proportion of equity held by institutional investors as a benchmark ownership share to evaluate the impact of changes in ownership structure on risk and profitability. Our aim is also to assess if publicly held and privately owned banks respond differently to such changes in terms of risk and profitability. We hence analyze the influence of market discipline by testing if ownership structure changes imply different levels of risk and profitability for listed banks.

Working on a panel of European commercial banks and using both asset risk and default risk measures, we find that changes in ownership structure are significant in explaining risk differences. However, by investigating the relationship further we note that such findings are mainly accurate for privately owned banks.

Specifically, we show that a shift in equity from institutional investors to either individuals/families or banking institutions implies a decrease in asset risk and default risk, but no change in profitability. This result is consistent with the conjecture 
that because individuals/families hold less diversified portfolios than institutional investors, they have incentives to take less risk. Regarding banking institutions, when their stakes in other banks are higher, they seem to encourage relatively conservative risk-taking strategies in their subsidiaries possibly for reputation concerns. Meanwhile, our results show that a shift in equity from institutional investors to nonfinancial companies does not involve changes in risk and profitability; this suggests that institutional investors and non-financial companies have similar risk-return objectives in the banks they are involved in. We also note that the level of ownership concentration/dispersion within each category of shareholders does not influence the relationship between ownership structure and risk.

We further find no significant differences in asset risk and default risk between publicly-held and privately-owned banks. Moreover, unlike for private banks, for public banks ownership structure changes do not affect risk taking. Market forces seem to align the risk-taking behavior of public banks and the ownership structure is no more a determinant to explain risk differences. Our results merely highlight that a higher involvement of banking institutions in public banks implies a lower exposure to credit risk and a lower probability of default. As bank supervisors provide guidelines for banks on safety and soundness, a close look at both the ownership structure and the nature of equity (public and tradable/ private and non tradable) could be important. 
Table 1. Distribution of banks by country

\begin{tabular}{|c|c|c|c|}
\hline & All banks & Non-listed banks & Listed banks \\
\hline Austria & 14 & 11 & 3 \\
\hline Belgium & 7 & 7 & 0 \\
\hline Denmark & 19 & 2 & 17 \\
\hline Finland & 2 & 0 & 2 \\
\hline France & 64 & 58 & 6 \\
\hline Germany & 39 & 33 & 6 \\
\hline Greece & 7 & 0 & 7 \\
\hline Ireland & 5 & 1 & 4 \\
\hline Italy & 17 & 4 & 13 \\
\hline Luxembourg & 33 & 32 & 1 \\
\hline Netherlands & 7 & 6 & 1 \\
\hline Portugal & 2 & 0 & 2 \\
\hline Spain & 15 & 3 & 12 \\
\hline Sweden & 2 & 0 & 2 \\
\hline Switzerland & 3 & 2 & 1 \\
\hline United Kingdom & 13 & 10 & 3 \\
\hline Total & 249 & 169 & 80 \\
\hline
\end{tabular}


Table 2. Descriptive statistics for our panel of 249 European Commercial banks, on average over the period 1999-2005

\begin{tabular}{|c|c|c|c|c|c|c|c|c|c|c|c|c|c|c|}
\hline & LOANS & DEP & EQUITY & EXPENSES & LLP & $\mathrm{ROA}$ & ROE & LIQUID & OBS & TA & SDROA & SDROE & $\mathrm{Z}$ & $\mathrm{ZP}$ \\
\hline \multicolumn{15}{|c|}{ Large sample of commercial banks available under Bankscope (1586 banks) } \\
\hline Mean & 46.58 & 26.72 & 12.13 & 1.95 & 0.68 & 0.82 & 8.03 & 29.16 & 29.05 & 10410 & 1.14 & 8.20 & 46.70 & 47.26 \\
\hline Maximum & 99.97 & 97.64 & 69.52 & 77.64 & 14.49 & 19.24 & 39.95 & 100.00 & 857.47 & 1330000 & 53.26 & 216.02 & 590.40 & 496.77 \\
\hline Minimum & 0.00 & 0.00 & 0.00 & 0.00 & -14.98 & -20.00 & -38.25 & 0.00 & 0.00 & 0.991 & 0.00 & 0.00 & 0.23 & 0.37 \\
\hline Std. Dev. & 29.72 & 26.73 & 11.77 & 3.04 & 1.95 & 2.28 & 9.97 & 26.75 & 75.07 & 64435 & 3.04 & 14.45 & 65.03 & 61.57 \\
\hline \multicolumn{15}{|l|}{ Our sample of 249 banks } \\
\hline Mean & 50.15 & 39.06 & 9.41 & 1.58 & 0.54 & 0.81 & 9.52 & 24.50 & 32.15 & 20200 & 0.58 & 6.98 & 44.03 & 37.17 \\
\hline Maximum & 94.71 & 93.31 & 68.24 & 41.78 & 9.09 & 16.59 & 30.82 & 87.09 & 887.90 & 839000 & 7.67 & 143.06 & 511.66 & 190.76 \\
\hline Minimum & 0.76 & 0.00 & 1.06 & 0.04 & -10.99 & -4.04 & -38.66 & 0.24 & 0.02 & 4554 & 0.01 & 0.003 & 0.56 & 0.51 \\
\hline Std. Dev. & 24.66 & 26.04 & 8.51 & 2.80 & 2.00 & 1.43 & 9.23 & 20.65 & 73.68 & 83900 & 0.94 & 12.81 & 56.13 & 32.35 \\
\hline T-statistic of the mean test & $-2.06^{* *}$ & $-6.92 * * *$ & $4.42 * * *$ & $1.91^{*}$ & 1.03 & 0.09 & $-2.34 * *$ & $3.16^{* * *}$ & -0.61 & $-1.76^{*}$ & $5.78 * * *$ & 1.37 & 0.68 & $3.92 * * *$ \\
\hline \multicolumn{15}{|l|}{ Non-listed banks (169) } \\
\hline Mean & 45.55 & 31.65 & 9.71 & 1.35 & 0.48 & 0.63 & 8.02 & 28.36 & 33.56 & 3820 & 0.61 & 7.77 & 43.63 & 36.98 \\
\hline Maximum & 94.71 & 93.31 & 66.78 & 7.73 & 9.09 & 4.87 & 30.82 & 87.09 & 887.90 & 52400 & 7.67 & 143.06 & 511.66 & 190.76 \\
\hline Minimum & 0.76 & 0.00 & 1.47 & 0.04 & -10.99 & -4.04 & -38.66 & 0.31 & 0.02 & 4554 & 0.01 & 0.003 & 0.56 & 0.51 \\
\hline Std. Dev. & 25.96 & 25.98 & 8.81 & 1.06 & 2.41 & 1.04 & 9.78 & 23.18 & 86.32 & 7990 & 0.97 & 14.74 & 58.64 & 32.35 \\
\hline \multicolumn{15}{|l|}{ Listed banks (80) } \\
\hline Mean & 59.87 & 54.71 & 8.79 & 2.05 & 0.66 & 1.18 & 12.67 & 16.33 & 29.10 & 54800 & 0.51 & 5.32 & 44.87 & 37.50 \\
\hline Maximum & 88.84 & 86.94 & 68.24 & 41.78 & 3.39 & 16.59 & 25.55 & 47.28 & 141.52 & 839000 & 5.58 & 50.93 & 396.34 & 136.62 \\
\hline Minimum & 9.09 & 3.84 & 1.06 & 0.04 & -0.98 & -2.86 & -20.21 & 0.24 & 0.90 & 57462 & 0.01 & 0.28 & 1.57 & 1.27 \\
\hline Std. Dev. & 18.28 & 18.09 & 7.84 & 4.68 & 0.54 & 1.98 & 7.00 & 9.87 & 32.76 & 142000 & 0.88 & 6.96 & 50.83 & 27.04 \\
\hline T-statistic of the mean test & $-4.43 * * *$ & $-7.15 * * *$ & 0.79 & $-1.84 *$ & -0.66 & $-2.87 * * *$ & $-3.81 * * *$ & $4.45 * * *$ & 0.44 & $-4.65 * * *$ & 0.79 & 1.41 & -0.16 & 0.46 \\
\hline
\end{tabular}

T statistics test for the null:"Descriptive statistics are not different between the two samples considered".***,** and * indicate significance respectively at the $1 \%, 5 \%$ and $10 \%$ levels for a bilateral test. Variable definitions (all variables are expressed in percentage except $T A$ which is in million of euros): $L O A N S=$ net loans/total assets; $D E P=$

deposits/total assets; $E Q U I T Y=$ equity/total assets; $E X P E N S E S=$ personnel expenses/total assets; $L L P=$ loan loss provision/net loans; $R O A=$ return on average assets; $R O E=$ return on average equity; $L I Q U I D=$ liquid assets/total assets; $O B S=$ off balance sheet/ total assets; $T A=$ total assets (millions Euros); $S D R O A=$ standard deviation of the ROA; $S D R O E=$ standard deviation of the ROE; $Z=Z$-score $=(100+$ average ROE $) / \mathrm{SDROE}$;

$Z P=\mathrm{ZP}$-score $=\frac{\text { average ROA }}{\text { SDROA }}+\frac{\text { average }(\text { Total equities } / \text { Total assets })}{\text { SDROA }}$. 
Table 3. Number of banks for which the ownership variables are different from zero and percentage of stock held by the different categories of owners

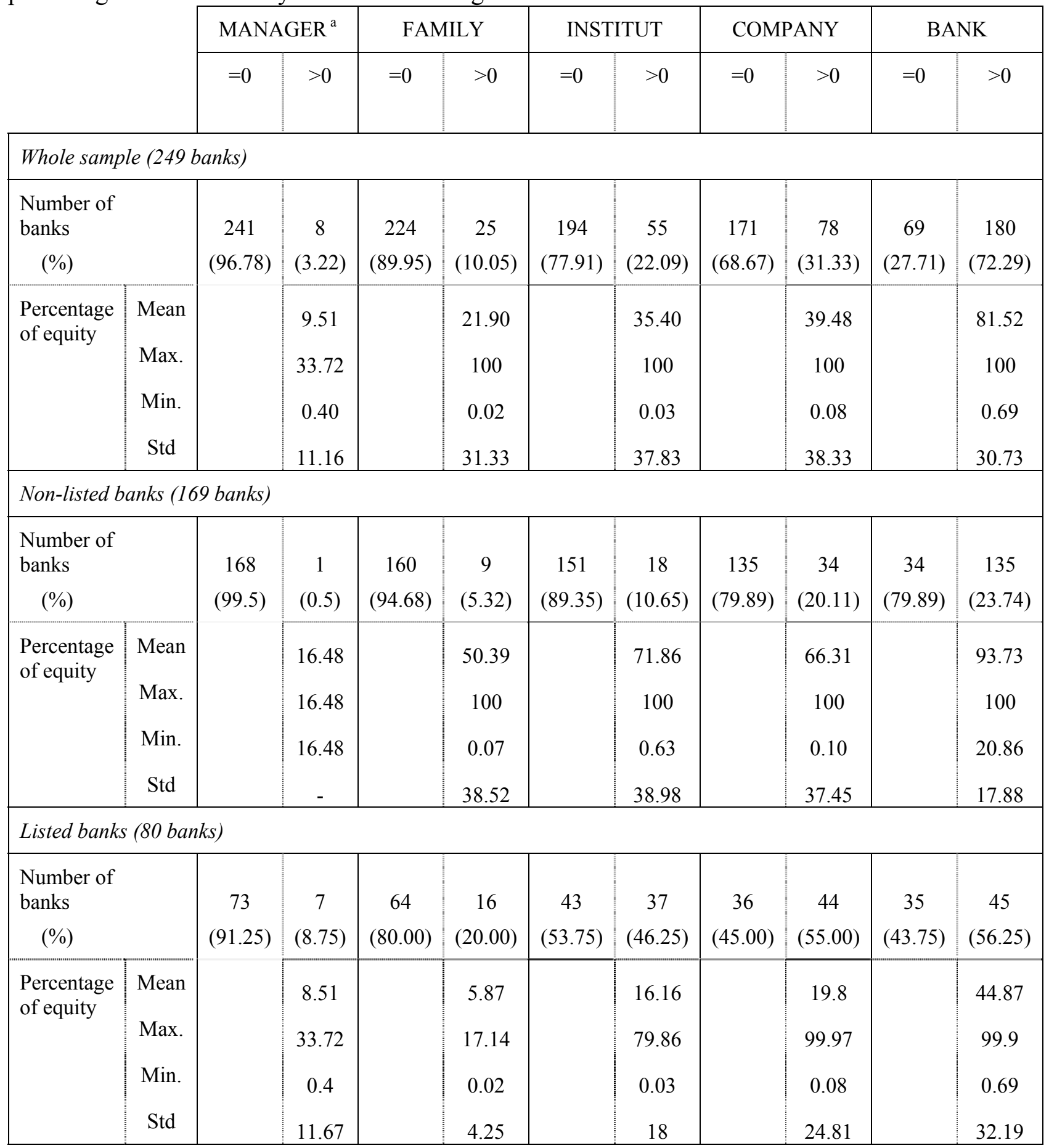

Five categories of owners are considered: (i) managers/directors (MANAGER); (ii) non-financial companies (COMPANY); (iii) individual/family investors (FAMILY); (iv) banks (BANK); and (v) institutional investors insurance company, financial companies and mutual \& pension funds - (INSTITUT).

${ }^{a}$ For example, in the whole sample, we have 241 banks in which managers do not hold equity and 8 banks in which managers hold equity. We also present the percentage of banks for which the variable MANAGER is equal to zero (96.78), as well as the percentage of equity held on average by the managers in the 8 banks in which they have a stake $(9.51 \%)$. 
Table 4. Distribution of our sample of privately-owned and publicly-owned banks according to the percentage of equity held by each category of shareholder

\begin{tabular}{|c|c|c|c|c|c|c|}
\hline & \multicolumn{6}{|c|}{ Percentage of equity held } \\
\hline & 0 & ]0-5] & ]5-33] & ]33-50] & ] $50-75]$ & ]75-100] \\
\hline \multicolumn{7}{|c|}{ Number of non listed banks (total of 169 banks) } \\
\hline MANAGER & 168 & 0 & 1 & 0 & 0 & 0 \\
\hline FAMILY & 160 & 1 & 2 & 2 & 1 & 3 \\
\hline INSTITUT & 151 & 3 & 1 & 1 & 3 & 11 \\
\hline COMPANY & 135 & 2 & 7 & 2 & 5 & 17 \\
\hline BANK & 34 & 0 & 4 & 5 & 4 & 122 \\
\hline \multicolumn{7}{|c|}{ Number of listed banks (total of 80 banks) } \\
\hline MANAGER & 73 & 3 & 3 & 1 & 0 & 0 \\
\hline FAMILY & 64 & 8 & 8 & 0 & 0 & 0 \\
\hline INSTITUT & 43 & 12 & 19 & 2 & 2 & 1 \\
\hline COMPANY & 36 & 13 & 24 & 2 & 3 & 3 \\
\hline BANK & 34 & 0 & 4 & 5 & 4 & 122 \\
\hline
\end{tabular}

Five categories of owners are considered: (i) managers/directors (MANAGER); (ii) non-financial companies (COMPANY); (iii) individual/family investors (FAMILY); (iv) banks (BANK); and (v) institutional investors - insurance company, financial companies and mutual \& pension funds (INSTITUT). 
Table 5. Risk measures and default risk measures according to the shareholder type and the percentage of equity held

\begin{tabular}{|c|c|c|c|c|c|c|c|}
\hline & & \multicolumn{6}{|c|}{ Percentage of equity held } \\
\hline & & 0 & ]0-5] & ]5-33] & ]33-50] & ]50-75] & ]75-100] \\
\hline \multirow{8}{*}{ MANAGER } & SDROA & 0.57 & 0.47 & 0.99 & 0.19 & - & - \\
\hline & SDROE & 6.88 & 9.20 & 12.23 & 2.70 & - & - \\
\hline & M_LLP & 0.32 & 0.71 & 0.48 & 0.57 & - & - \\
\hline & $\mathrm{Z}^{-}$ & 44.60 & 33.15 & 18.11 & 44.91 & - & - \\
\hline & $\mathrm{ZP}$ & 50.38 & 33.32 & 19.14 & 50.96 & - & - \\
\hline & ZP1 & 4.25 & 3.37 & 2.27 & 8.93 & - & - \\
\hline & $\mathrm{ZP} 2$ & 46.13 & 29.95 & 16.87 & 42.04 & - & - \\
\hline & Observations & 241 & 3 & 4 & 1 & 0 & 0 \\
\hline \multirow{8}{*}{ FAMILY } & SDROA & 0.58 & 0.57 & 0.54 & 0.46 & 0.12 & 0.15 \\
\hline & SDROE & 7.24 & 5.31 & 4.51 & 7.27 & 2.23 & 2.27 \\
\hline & M LLP & 0.34 & -0.22 & 0.71 & 0.26 & 0.75 & 0.14 \\
\hline & $\mathrm{Z}$ & 44.19 & 28.35 & 39.21 & 109.51 & 49.37 & 49.96 \\
\hline & $\mathrm{ZP}$ & 50.80 & 31.09 & 31.79 & 95.20 & 53.26 & 48.98 \\
\hline & ZP1 & 4.26 & 3.58 & 3.55 & 7.69 & 4.69 & 3.22 \\
\hline & ZP2 & 46.54 & 27.70 & 28.24 & 87.51 & 48.57 & 45.75 \\
\hline & Observations & 224 & 9 & 10 & 2 & 1 & 3 \\
\hline \multirow{8}{*}{ INSTITUT } & SDROA & 0.57 & 0.20 & 0.49 & 0.34 & 0.25 & 1.41 \\
\hline & SDROE & 7.20 & 3.11 & 6.29 & 4.24 & 3.56 & 11.45 \\
\hline & M_LLP & 0.17 & 0.29 & 0.74 & 0.46 & 1.38 & 1.80 \\
\hline & Z & 43.37 & 86.80 & 30.75 & 36.54 & 65.11 & 16.43 \\
\hline & $\mathrm{ZP}$ & 49.32 & 109.34 & 26.90 & 43.89 & 59.90 & 16.13 \\
\hline & ZP1 & 4.15 & 8.63 & 3.29 & 3.27 & 4.83 & 1.49 \\
\hline & ZP2 & 45.16 & 100.00 & 23.61 & 40.61 & 55.06 & 14.63 \\
\hline & Observations & 194 & 15 & 20 & 3 & 5 & 12 \\
\hline \multirow{8}{*}{ COMPANY } & SDROA & 0.62 & 0.23 & 0.30 & 0.27 & 0.20 & 0.93 \\
\hline & SDROE & 7.19 & 3.02 & 4.66 & 1.83 & 2.54 & 14.53 \\
\hline & M_LLP & 0.28 & 0.49 & 0.34 & 0.46 & 0.64 & 0.50 \\
\hline & $\mathrm{Z}$ & 37.51 & 84.66 & 54.60 & 107.90 & 70.97 & 28.31 \\
\hline & $\mathrm{ZP}$ & 47.84 & 48.98 & 67.88 & 63.66 & 74.89 & 24.54 \\
\hline & ZP1 & 3.91 & 5.60 & 6.47 & 5.08 & 4.69 & 2.16 \\
\hline & $\mathrm{ZP} 2$ & 43.98 & 43.38 & 61.41 & 58.58 & 70.19 & 22.38 \\
\hline & Observations & 171 & 15 & 31 & 4 & 8 & 20 \\
\hline \multirow{8}{*}{ BANK } & \begin{tabular}{|l|} 
SDROA \\
\end{tabular} & 0.75 & 0.30 & 0.37 & 0.14 & 0.31 & 0.58 \\
\hline & SDROE & 8.78 & 3.57 & 6.03 & 1.79 & 3.68 & 7.04 \\
\hline & M_LLP & 0.84 & 0.52 & 0.71 & 1.05 & 0.83 & -0.11 \\
\hline & $\mathrm{Z}$ & 32.15 & 35.58 & 47.26 & 78.66 & 43.10 & 48.09 \\
\hline & $\mathrm{ZP}$ & 34.69 & 34.30 & 65.79 & 67.14 & 46.15 & 55.22 \\
\hline & ZP1 & 3.72 & 4.59 & 7.13 & 6.50 & 3.77 & 3.97 \\
\hline & $\mathrm{ZP} 2$ & 30.96 & 29.71 & 58.65 & 60.63 & 42.37 & 51.24 \\
\hline & Observations & 69 & 5 & 19 & 8 & 17 & 131 \\
\hline
\end{tabular}

The variables MANAGER, FAMILY, INSTITUT, COMPANY and BANK represent the percentage of stock held respectively by managers/directors, families/individuals, institutional investors, nonfinancial companies, and banks.

Variable definitions (standard deviations and means are computed over the period 1999-2005): $S D R O A=$ standard deviation of the return on average assets; $S D R O E=$ standard deviation of return on average equity, $M_{-} L L P=$ Mean of the ratio of loan loss provision to net loans over the sample period; $Z=Z$-score $=(100+$ average $\mathrm{ROE}) / \mathrm{SDROE}$;

$Z P=\mathrm{ZP}$-score $=Z P 1+Z P 2=\frac{\text { average ROA }}{\mathrm{SDROA}}+\frac{\text { average }(\text { Total equities } / \text { Total assets })}{\text { SDROA }} ; Z P 1=$ measure of bank portfolio risk; $Z P 2=$ measure of leverage risk. 
Table 6. Ownership dispersion by shareholder category

\begin{tabular}{|l|c|c|c|c|}
\hline & Mean & Std. Dev. & Minimum & Maximum \\
\hline Whole sample & 0.775 & 0.297 & 0.054 & 1 \\
\hline HERF & 0.948 & 0.145 & 0.589 & 1 \\
\hline By shareholder category & 0.351 & 0 & 1 \\
\hline HERF_MANAGER & 0.654 & 0.349 & 0 & 1 \\
\hline HERF_FAMILY & 0.696 & 0.276 & 0.170 & 1 \\
\hline HERF_INSTITUT & 0.777 & 0.224 & 0 & 1 \\
\hline HERF_COMPANY & 0.888 & . & 0 \\
\hline HERF_BANK &
\end{tabular}

HERF is the Herfindahl index computed when we consider all the categories of shareholders together.

HERF $\_$j represents the Herfindahl index computed for the category of shareholder $j$ (by considering only shareholders who hold equity). Our Herfindahl index is defined for each bank $i$ as $\sum_{\mathrm{j}=1}^{\mathrm{n}} \mathrm{OS}_{\mathrm{j}}^{2}$, where $\mathrm{OS}_{\mathrm{j}}$ is the ratio of the percentage of equity held by each shareholder for the given category $j$ to the total percentage of equity held by all the shareholder of this category $j$.

We consider five categories of owners: (i) managers/directors (MANAGER); (ii) non-financial companies (COMPANY); (iii) individual/family investors (FAMILY); (iv) banks (BANK); and (v) institutional investors - insurance company, financial companies and mutual \& pension funds (INSTITUT).

Table 7. Average number of shareholders by category

\begin{tabular}{|c|c|c|c|c|}
\hline & Mean & Std. Dev. & Minimum & Maximum \\
\hline \multicolumn{5}{|l|}{ Whole sample } \\
\hline & 4.73 & 8.21 & 1 & 87 \\
\hline \multicolumn{5}{|c|}{ By Shareholder categories } \\
\hline MANAGER & 1.12 & 0.35 & 1 & 2 \\
\hline FAMILY & 2.48 & 2.29 & 1 & 8 \\
\hline INSTITUT & 2.96 & 2.81 & 1 & 12 \\
\hline COMPANY & 4.25 & 8.66 & 1 & 66 \\
\hline BANK & 2.13 & 3.95 & 1 & 52 \\
\hline
\end{tabular}

Five categories of owners are considered: (i) managers/directors (MANAGER); (ii) non-financial companies (COMPANY); (iii) individual/family investors (FAMILY); (iv) banks (BANK); and (v) institutional investors - insurance company, financial companies and mutual \& pension funds (INSTITUT).

Table 8. Ownership concentration and bank risk and profitability

\begin{tabular}{|c|c|c|c|c|c|c|}
\hline & Level of concentration & MANAGER & FAMILY & INSTITUT & COMPANY & BANK \\
\hline \multirow{3}{*}{ SDROA } & $\begin{array}{l}\text { Less Concentrated } \\
(\mathrm{HERF} \leq 0.5)\end{array}$ & - & 0.43 & 0.52 & 0.32 & 0.23 \\
\hline & $\begin{array}{l}\text { More Concentrated } \\
(\text { HERF }>0.5)\end{array}$ & 0.64 & 0.50 & 0.56 & 0.49 & 0.54 \\
\hline & T-stat of the mean test & - & -0.38 & -0.10 & -1.54 & $-3.68 * * *$ \\
\hline \multirow{3}{*}{ Z } & $\begin{array}{l}\text { Less Concentrated } \\
(\mathrm{HERF} \leq 0.5)\end{array}$ & - & 45.42 & 34.27 & 43.38 & 73.24 \\
\hline & $\begin{array}{l}\text { More Concentrated } \\
(\text { HERF }>0.5)\end{array}$ & 27.10 & 41.29 & 57.11 & 61.78 & 45.61 \\
\hline & T-stat of the mean test & - & 0.22 & -0.80 & -1.15 & 1.04 \\
\hline \multirow{3}{*}{ M_ROA } & $\begin{array}{l}\text { Less Concentrated } \\
(\mathrm{HERF} \leq 0.5)\end{array}$ & - & 1.08 & 1.10 & 0.83 & 0.46 \\
\hline & $\begin{array}{l}\text { More Concentrated } \\
(\text { HERF }>0.5)\end{array}$ & 0.82 & 1.35 & 1.58 & 0.94 & 0.66 \\
\hline & T-stat of the mean test $t$ & - & -0.65 & -0.45 & -0.61 & $-1.92 *$ \\
\hline
\end{tabular}

T statistics test for the null:"Risk and performance are not different for banks with a more or less concentrated ownership".***,** and * indicate significance respectively at the $1 \%, 5 \%$ and $10 \%$ levels for a bilateral test. The level of concentration is measured by our Herfindahl index (see definition in Table 6); a category of shareholder is considered with a more or less concentrated ownership when the Herfindahl index is respectively higher than 0.5 or strictly lower than 0.5 . Five categories of owners are considered: (i) managers/directors (MANAGER); (ii) nonfinancial companies (COMPANY); (iii) individual/family investors (FAMILY); (iv) banks (BANK); and (v) institutional investors - insurance company, financial companies and mutual \& pension funds - (INSTITUT). 
Table 9. Influence of ownership structure on the risk-taking behavior and profitability of banks (Model 1), cross-section OLS regressions

\begin{tabular}{|c|c|c|c|c|c|c|c|c|c|}
\hline & \multicolumn{3}{|c|}{ Risk measures } & \multicolumn{4}{|c|}{ Default Risk measures } & \multicolumn{2}{|c|}{ Profitability measures } \\
\hline & SDROA & SDROE & M LLP & $\mathrm{Z}$ & $\mathrm{ZP}$ & ZP1 & $\mathrm{ZP2}$ & M ROA & M ROE \\
\hline CONSTANT & $\begin{array}{l}0.200 \\
(0.27)\end{array}$ & $\begin{array}{l}-3.866 \\
(-0.32) \\
\end{array}$ & $\begin{array}{l}3.456^{*} \\
(1.83)\end{array}$ & $\begin{array}{l}38.95 \\
(1.28)\end{array}$ & $\begin{array}{l}15.63 \\
(0.34)\end{array}$ & $\begin{array}{l}-2.772 \\
(-0.47) \\
\end{array}$ & $\begin{array}{l}18.40 \\
(0.45)\end{array}$ & $\begin{array}{c}2.877^{* * *} \\
(3.56)\end{array}$ & $\begin{array}{c}23.56^{* * *} \\
(3.33)\end{array}$ \\
\hline MANAGER & $\begin{array}{c}0.00364 \\
(0.34)\end{array}$ & $\begin{array}{c}-0.0233 \\
(-0.14)\end{array}$ & $\begin{array}{c}-0.0295^{*} \\
(-1.68)\end{array}$ & $\begin{array}{c}-0.853^{*} \\
(-1.83)\end{array}$ & $\begin{array}{l}-0.576 \\
(-1.09)\end{array}$ & $\begin{array}{c}-0.0654 \\
(-0.99)\end{array}$ & $\begin{array}{l}-0.511 \\
(-1.07)\end{array}$ & $\begin{array}{c}0.0225^{* *} \\
(2.54)\end{array}$ & $\begin{array}{c}0.299^{* *} \\
(2.39)\end{array}$ \\
\hline FAMILY & $\begin{array}{c}-0.00455^{*} \\
(-1.72)\end{array}$ & $\begin{array}{c}-0.0834^{* * *} \\
(-2.77)\end{array}$ & $\begin{array}{c}-0.0179^{* *} \\
(-2.27)\end{array}$ & $\begin{array}{c}0.408^{* * *} \\
(2.16)\end{array}$ & $\begin{array}{l}0.141 \\
(0.77)\end{array}$ & $\begin{array}{c}-0.00318 \\
(-0.19)\end{array}$ & $\begin{array}{l}0.144 \\
(0.84)\end{array}$ & $\begin{array}{c}-0.000763 \\
(-0.21)\end{array}$ & $\begin{array}{c}0.00369 \\
(0.11)\end{array}$ \\
\hline COMPANY & $\begin{array}{c}-0.00285 \\
(-1.12)\end{array}$ & $\begin{array}{c}0.0369 \\
(0.54)\end{array}$ & $\begin{array}{c}-0.00973 \\
(-1.15)\end{array}$ & $\begin{array}{l}0.181 \\
(1.31)\end{array}$ & $\begin{array}{c}-0.00877 \\
(-0.07)\end{array}$ & $\begin{array}{c}-0.0149 \\
(-1.04)\end{array}$ & $\begin{array}{c}0.00613 \\
(0.05)\end{array}$ & $\begin{array}{c}-0.00196 \\
(-0.58)\end{array}$ & $\begin{array}{c}-0.00268 \\
(-0.07)\end{array}$ \\
\hline BANK & $\begin{array}{c}-0.00142 \\
(-0.68)\end{array}$ & $\begin{array}{c}-0.0267 \\
(-1.05)\end{array}$ & $\begin{array}{c}-0.0120^{*} \\
(-1.77)\end{array}$ & $\begin{array}{l}0.230^{*} \\
(1.75)\end{array}$ & $\begin{array}{c}0.0942 \\
(0.73)\end{array}$ & $\begin{array}{c}-0.00269 \\
(-0.17)\end{array}$ & $\begin{array}{c}0.0969 \\
(0.83)\end{array}$ & $\begin{array}{c}-0.000967 \\
(-0.41)\end{array}$ & $\begin{array}{c}-0.00681 \\
(-0.28)\end{array}$ \\
\hline M_LNTA & $\begin{array}{r}0.0660^{*} \\
(1.94)\end{array}$ & $\begin{array}{l}1.189^{*} \\
(1.89)\end{array}$ & $\begin{array}{l}-0.113 \\
(-1.24)\end{array}$ & $\begin{array}{l}-4.439^{* *} \\
(-2.17)\end{array}$ & $\begin{array}{l}-3.657 \\
(-1.20)\end{array}$ & $\begin{array}{c}0.0899 \\
(0.32)\end{array}$ & $\begin{array}{l}-3.747 \\
(-1.30)\end{array}$ & $\begin{array}{c}-0.0916^{* *} \\
(-2.11)\end{array}$ & $\begin{array}{l}-0.347 \\
(-1.06)\end{array}$ \\
\hline M_OEQUITY & $\begin{array}{c}0.0660^{* * * *} \\
(6.65)\end{array}$ & $\begin{array}{c}-0.00333 \\
(-0.04)\end{array}$ & $\begin{array}{c}-0.0561^{* *} \\
(-2.16)\end{array}$ & $\begin{array}{l}-0.262 \\
(-0.59)\end{array}$ & $\begin{array}{l}-0.889 \\
(-1.49)\end{array}$ & $\begin{array}{l}-0.101 \\
(-1.64)\end{array}$ & $\begin{array}{l}-0.788 \\
(-1.41)\end{array}$ & $\begin{array}{c}0.0460^{* *} \\
(2.50)\end{array}$ & $\begin{array}{l}-0.126 \\
(-1.36)\end{array}$ \\
\hline M_DEPOSIT & $\begin{array}{c}-0.00237 \\
(-1.11)\end{array}$ & $\begin{array}{c}-0.00944 \\
(-0.25)\end{array}$ & $\begin{array}{c}-0.0114 \\
(-1.29)\end{array}$ & $\begin{array}{l}0.157 \\
(0.74)\end{array}$ & $\begin{array}{c}0.0907 \\
(0.33)\end{array}$ & $\begin{array}{c}-0.0655^{* * *} \\
(-2.94)\end{array}$ & $\begin{array}{l}0.156 \\
(0.60)\end{array}$ & $\begin{array}{c}-0.00697^{* *} \\
(-2.32)\end{array}$ & $\begin{array}{c}-0.101^{* * *} \\
(-3.75)\end{array}$ \\
\hline LISTED & $\begin{array}{l}0.270 \\
(0.60)\end{array}$ & $\begin{array}{l}4.585 \\
(0.85)\end{array}$ & $\begin{array}{l}-0.411 \\
(-0.55)\end{array}$ & $\begin{array}{l}3.652 \\
(0.17)\end{array}$ & $\begin{array}{l}28.92 \\
(0.91)\end{array}$ & $\begin{array}{l}8.927^{*} \\
(1.97)\end{array}$ & $\begin{array}{l}20.00 \\
(0.72)\end{array}$ & $\begin{array}{l}-0.447 \\
(-1.08)\end{array}$ & $\begin{array}{l}0.913 \\
(0.21)\end{array}$ \\
\hline LAMBDA & $\begin{array}{c}0.0463 \\
(1.02)\end{array}$ & $\begin{array}{l}1.209 \\
(1.46)\end{array}$ & $\begin{array}{l}-0.109 \\
(-0.55)\end{array}$ & $\begin{array}{l}1.066 \\
(0.36)\end{array}$ & $\begin{array}{l}6.554 \\
(1.42)\end{array}$ & $\begin{array}{l}0.0387 \\
(0.10)\end{array}$ & $\begin{array}{l}6.516 \\
(1.48)\end{array}$ & $\begin{array}{c}-0.180^{* * *} \\
(-2.85)\end{array}$ & $\begin{array}{c}-2.108^{* * *} \\
(-3.27)\end{array}$ \\
\hline LAMBDA*LISTED & $\begin{array}{l}-0.188 \\
(-0.52)\end{array}$ & $\begin{array}{l}-3.912 \\
(-0.82)\end{array}$ & $\begin{array}{l}-0.112 \\
(-0.31)\end{array}$ & $\begin{array}{l}2.215 \\
(0.16)\end{array}$ & $\begin{array}{l}-16.18 \\
(-0.72)\end{array}$ & $\begin{array}{l}-5.897^{*} \\
(-1.81)\end{array}$ & $\begin{array}{l}-10.28 \\
(-0.52)\end{array}$ & $\begin{array}{l}0.164 \\
(0.43)\end{array}$ & $\begin{array}{l}-1.725 \\
(-0.55)\end{array}$ \\
\hline COUNTRY DUMMIES & Yes & Yes & Yes & Yes & Yes & Yes & Yes & Yes & Yes \\
\hline Number of obs. & 244 & 244 & 241 & 242 & 244 & 244 & 244 & 244 & 243 \\
\hline R2 & 0.296 & 0.0848 & 0.105 & 0.119 & 0.0571 & 0.153 & 0.0542 & 0.304 & 0.226 \\
\hline
\end{tabular}

$* * *, * *$ and $*$ indicate significance at the $1 \%, 5 \%$ and $10 \%$ levels respectively. t-statistics are corrected for heteroskedasticity following White's methodology. Variable definitions (standard deviations and means are computed over the period 1999-2005): SDROA= standard deviation of the return on average assets; SDROE $=$ standard deviation of the return on average equity, $M_{-} L L P=$ mean of the ratio of loan loss provisions to net loans; $Z=\mathrm{Z}$-score; $Z P=\mathrm{ZP}$-score; $Z P 1=$ measure of bank portfolio risk; $Z P 2=$ measure of leverage risk; $M R O A=$ mean of the return on average asset; $M R O E=$ mean of the return on average equity; $M L N T A=$ mean of the natural logarithm of total asset; $M \_O E Q U I T Y=$ mean of the ratio of equity to total assets orthogonalized with TA; $M \_D E P O S I T=$ mean of the ratio of deposits to total assets; $L I S T E D=$ a dummy variable which takes the value of one if the bank is listed on the stock market and zero otherwise; $L A M B D A$ is the inverse Mills ratio estimated for each bank from the first-stage Probit model. The variables MANAGER, FAMILY, COMPANY and BANK represent the percentage of stock held respectively by managers/directors, families/individuals, non-financial companies and banks. We also include dummy variables to account for country specific effects. 
Table10. Influence of ownership structure on the risk-taking behavior and profitability of listed and non-listed banks (Model 2), cross-section OLS regressions

\begin{tabular}{|c|c|c|c|c|c|c|c|c|c|}
\hline & \multicolumn{3}{|c|}{ Risk measures } & \multicolumn{4}{|c|}{ Default Risk measures } & \multicolumn{2}{|c|}{ Profitability measures } \\
\hline & SDROA & SDROE & M LLP & $\mathrm{Z}$ & $\mathrm{ZP}$ & $\mathrm{ZP} 1$ & ZP2 & M ROA & M ROE \\
\hline $\operatorname{CONSTANT}\left(\beta_{0}\right)$ & $\begin{array}{l}0.336 \\
(0.47)\end{array}$ & $\begin{array}{l}-2.878 \\
(-0.24)\end{array}$ & $\begin{array}{l}3.869^{*} \\
(1.89)\end{array}$ & $\begin{array}{l}59.19^{*} \\
(1.83)\end{array}$ & $\begin{array}{l}4.433 \\
(0.09)\end{array}$ & $\begin{array}{l}-4.294 \\
(-0.68)\end{array}$ & $\begin{array}{l}8.728 \\
(0.20)\end{array}$ & $\begin{array}{l}2.772^{* * *} \\
(3.59)\end{array}$ & $\begin{array}{c}24.25^{* * *} \\
(3.29)\end{array}$ \\
\hline $\operatorname{FAMILY}\left(\beta_{1}\right)$ & $\begin{array}{c}-0.00466 \\
(-1.55)\end{array}$ & $\begin{array}{l}-0.0810^{* *} \\
(-2.49)\end{array}$ & $\begin{array}{r}-0.0209^{*} \\
(-1.95)\end{array}$ & $\begin{array}{l}0.283 \\
(1.59)\end{array}$ & $\begin{array}{l}0.283 \\
(1.64)\end{array}$ & $\begin{array}{c}0.0146 \\
(1.15)\end{array}$ & $\begin{array}{l}0.268 \\
(1.65)\end{array}$ & $\begin{array}{c}0.000322 \\
(0.08)\end{array}$ & $\begin{array}{c}-0.000599 \\
(-0.02)\end{array}$ \\
\hline $\operatorname{COMPANY}\left(\beta_{2}\right)$ & $\begin{array}{c}-0.00311 \\
(-0.95)\end{array}$ & $\begin{array}{l}0.0487 \\
(0.58)\end{array}$ & $\begin{array}{c}-0.0129 \\
(-1.16)\end{array}$ & $\begin{array}{c}0.0828 \\
(0.51)\end{array}$ & $\begin{array}{l}0.0878 \\
(0.62)\end{array}$ & $\begin{array}{c}-0.000719 \\
(-0.06)\end{array}$ & $\begin{array}{l}0.0885 \\
(0.66)\end{array}$ & $\begin{array}{c}-0.00104 \\
(-0.27)\end{array}$ & $\begin{array}{c}-0.00737 \\
(-0.15)\end{array}$ \\
\hline $\operatorname{BANK}\left(\beta_{3}\right)$ & $\begin{array}{c}-0.00210 \\
(-0.75)\end{array}$ & $\begin{array}{l}-0.0315 \\
(-1.00)\end{array}$ & $\begin{array}{c}-0.0147 \\
(-1.51)\end{array}$ & $\begin{array}{l}0.0881 \\
(0.62)\end{array}$ & $\begin{array}{l}0.234 \\
(1.63)\end{array}$ & $\begin{array}{l}0.0147 \\
(1.07)\end{array}$ & $\begin{array}{l}0.219 \\
(1.65)\end{array}$ & $\begin{array}{c}-0.000351 \\
(-0.12)\end{array}$ & $\begin{array}{l}-0.0175 \\
(-0.56)\end{array}$ \\
\hline FAMILY*LISTED $\left(\beta_{4}\right)$ & $\begin{array}{c}-0.0182 \\
(-1.38)\end{array}$ & $\begin{array}{l}-0.131 \\
(-0.73)\end{array}$ & $\begin{array}{l}0.0133 \\
(0.66)\end{array}$ & $\begin{array}{l}0.317 \\
(0.45)\end{array}$ & $\begin{array}{l}-2.054 \\
(-1.33)\end{array}$ & $\begin{array}{l}-0.226 \\
(-1.00)\end{array}$ & $\begin{array}{l}-1.828 \\
(-1.37)\end{array}$ & $\begin{array}{c}-0.0141 \\
(-0.74)\end{array}$ & $\begin{array}{c}-0.0331 \\
(-0.18)\end{array}$ \\
\hline COMPANY*LISTED $\left(\beta_{5}\right)$ & $\begin{array}{c}-0.000409 \\
(-0.09)\end{array}$ & $\begin{array}{c}-0.0719 \\
(-0.82)\end{array}$ & $\begin{array}{l}0.0111 \\
(1.08)\end{array}$ & $\begin{array}{l}0.209 \\
(0.83)\end{array}$ & $\begin{array}{l}-0.179 \\
(-0.67)\end{array}$ & $\begin{array}{c}-0.0332 \\
(-0.99)\end{array}$ & $\begin{array}{l}-0.145 \\
(-0.60)\end{array}$ & $\begin{array}{c}-0.00396 \\
(-0.66)\end{array}$ & $\begin{array}{c}-0.00591 \\
(-0.11)\end{array}$ \\
\hline $\operatorname{BANK} * \operatorname{LISTED}\left(\beta_{6}\right)$ & $\begin{array}{c}0.00195 \\
(0.43)\end{array}$ & $\begin{array}{c}0.0290 \\
(0.55)\end{array}$ & $\begin{array}{c}0.00854 \\
(0.86)\end{array}$ & $\begin{array}{l}0.481 \\
(1.56)\end{array}$ & $\begin{array}{l}-0.445^{*} \\
(-1.68)\end{array}$ & $\begin{array}{c}-0.0532 \\
(-1.55)\end{array}$ & $\begin{array}{l}-0.391^{*} \\
(-1.67)\end{array}$ & $\begin{array}{c}-0.00254 \\
(-0.47)\end{array}$ & $\begin{array}{c}0.0235 \\
(0.47)\end{array}$ \\
\hline M_LNTA $\left(\beta_{7}\right)$ & $\begin{array}{c}0.0656^{*} \\
(1.93)\end{array}$ & $\begin{array}{l}1.183^{*} \\
(1.90)\end{array}$ & $\begin{array}{l}-0.114 \\
(-1.24)\end{array}$ & $\begin{array}{c}-4.434^{* *} \\
(-2.16)\end{array}$ & $\begin{array}{l}-3.908 \\
(-1.29)\end{array}$ & $\begin{array}{c}0.0614 \\
(0.23)\end{array}$ & $\begin{array}{l}-3.970 \\
(-1.38)\end{array}$ & $\begin{array}{c}-0.0902^{* *} \\
(-2.07)\end{array}$ & $\begin{array}{l}-0.309 \\
(-0.93)\end{array}$ \\
\hline M_OEQUITY $\left(\beta_{8}\right)$ & $\begin{array}{c}0.0659^{* * *} \\
(6.67)\end{array}$ & $\begin{array}{c}-0.00594 \\
(-0.06)\end{array}$ & $\begin{array}{c}-0.0573^{* *} \\
(-2.25)\end{array}$ & $\begin{array}{l}-0.317 \\
(-0.73)\end{array}$ & $\begin{array}{l}-0.833 \\
(-1.38)\end{array}$ & $\begin{array}{c}-0.0944 \\
(-1.54)\end{array}$ & $\begin{array}{l}-0.738 \\
(-1.31)\end{array}$ & $\begin{array}{c}0.0463^{* *} \\
(2.49)\end{array}$ & $\begin{array}{l}-0.129 \\
(-1.40)\end{array}$ \\
\hline M_DEPOSIT $\left(\beta_{9}\right)$ & $\begin{array}{c}-0.00209 \\
(-0.96)\end{array}$ & $\begin{array}{c}-0.00657 \\
(-0.17)\end{array}$ & $\begin{array}{c}-0.0108 \\
(-1.23)\end{array}$ & $\begin{array}{l}0.192 \\
(0.88)\end{array}$ & $\begin{array}{c}0.0658 \\
(0.24)\end{array}$ & $\begin{array}{c}-0.0687^{* * *} \\
(-2.92)\end{array}$ & $\begin{array}{l}0.134 \\
(0.51)\end{array}$ & $\begin{array}{c}-0.00702^{* *} \\
(-2.25)\end{array}$ & $\begin{array}{c}-0.0978^{* * *} \\
(-3.53)\end{array}$ \\
\hline $\operatorname{LISTED}\left(\beta_{10}\right)$ & $\begin{array}{l}0.188 \\
(0.44)\end{array}$ & $\begin{array}{l}4.235 \\
(0.76)\end{array}$ & $\begin{array}{l}-0.992 \\
(-0.90)\end{array}$ & $\begin{array}{l}-22.65 \\
(-1.00)\end{array}$ & $\begin{array}{l}52.67 \\
(1.31)\end{array}$ & $\begin{array}{l}11.93^{* *} \\
(2.00)\end{array}$ & $\begin{array}{l}40.74 \\
(1.17)\end{array}$ & $\begin{array}{l}-0.255 \\
(-0.52)\end{array}$ & $\begin{array}{c}0.0594 \\
(0.01)\end{array}$ \\
\hline $\operatorname{LAMBDA}\left(\beta_{11}\right)$ & $\begin{array}{c}0.0472 \\
(1.04)\end{array}$ & $\begin{array}{l}1.180 \\
(1.46)\end{array}$ & $\begin{array}{l}-0.104 \\
(-0.52)\end{array}$ & $\begin{array}{l}1.210 \\
(0.41)\end{array}$ & $\begin{array}{l}6.397 \\
(1.37)\end{array}$ & $\begin{array}{l}0.0135 \\
(0.04)\end{array}$ & $\begin{array}{l}6.384 \\
(1.44)\end{array}$ & $\begin{array}{c}-0.181^{* * *} \\
(-2.83)\end{array}$ & $\begin{array}{c}-2.085^{* * *} \\
(-3.23)\end{array}$ \\
\hline $\operatorname{LAMBDA} * \operatorname{LISTED}\left(\beta_{12}\right)$ & $\begin{array}{l}-0.182 \\
(-0.53)\end{array}$ & $\begin{array}{l}-3.403 \\
(-0.76)\end{array}$ & $\begin{array}{l}-0.148 \\
(-0.43)\end{array}$ & $\begin{array}{l}2.604 \\
(0.18)\end{array}$ & $\begin{array}{l}-17.01 \\
(-0.78)\end{array}$ & $\begin{array}{l}-5.922^{*} \\
(-1.84)\end{array}$ & $\begin{array}{l}-11.09 \\
(-0.57)\end{array}$ & $\begin{array}{l}0.177 \\
(0.47)\end{array}$ & $\begin{array}{l}-1.612 \\
(-0.51)\end{array}$ \\
\hline COUNTRY DUMMIES & Yes & Yes & Yes & Yes & Yes & Yes & Yes & Yes & Yes \\
\hline Risk level to reject $\beta_{1}+\beta_{4}=0$ & $0.0764 *$ & 0.228 & 0.626 & 0.376 & 0.249 & 0.346 & 0.240 & 0.458 & 0.856 \\
\hline Risk level to reject $\beta_{2}+\beta_{5}=0$ & 0.311 & 0.603 & 0.723 & 0.159 & 0.700 & 0.289 & 0.788 & 0.347 & 0.745 \\
\hline Risk level to reject $\beta_{3}+\beta_{6}=0$ & 0.965 & 0.951 & $0.0786^{*}$ & $0.0432 * *$ & 0.342 & 0.245 & 0.369 & 0.519 & 0.879 \\
\hline Number of obs. & 244 & 244 & 241 & 242 & 244 & 244 & 244 & 244 & 243 \\
\hline $\mathrm{R} 2$ & 0.298 & 0.0908 & 0.107 & 0.128 & 0.0616 & 0.159 & 0.0582 & 0.302 & 0.222 \\
\hline
\end{tabular}

$* * *, * *$ and $*$ indicate significance at the $1 \%, 5 \%$ and $10 \%$ levels respectively. t-statistics are corrected for heteroskedasticity following White's methodology.

Variable definitions (standard deviations and means are computed over the period 1999-2005): SDROA= standard deviation of the return on average assets; $S D R O E=$ standard deviation of the return on average equity, $M L L P=$ mean of the ratio of loan loss provisions to net loans; $Z=Z$-score; $Z P=Z \mathrm{P}$-score; $Z P I=$ measure of bank portfolio risk; $Z P 2=$ measure of leverage risk; $M-R O A=$ mean

of the return on average asset; $M_{-} R O E=$ mean of the return on average equity; $M_{-} L N T A=$ mean of the natural logarithm of total asset; $M_{-} O E Q U I T Y=$ mean of the ratio of equity to total assets orthogonalized with TA; $M_{-} D E P O S I T=$ mean of the ratio of deposits to total assets; $L I S T E D=$ a dummy variable which takes the value of one if the bank is listed on the stock market and zero otherwise

LAMBDA is the inverse Mills ratio estimated for each bank from the first-stage Probit model. The variables FAMILY, COMPANY and BANK represent the percentage of stock held respectively by families/individuals, non-financial companies and banks. We also include dummy variables to account for country specific effects. 
Figure 1. Asset risk, default risk, profitability and asset growth rate for public and private banks according to their main category of shareholder
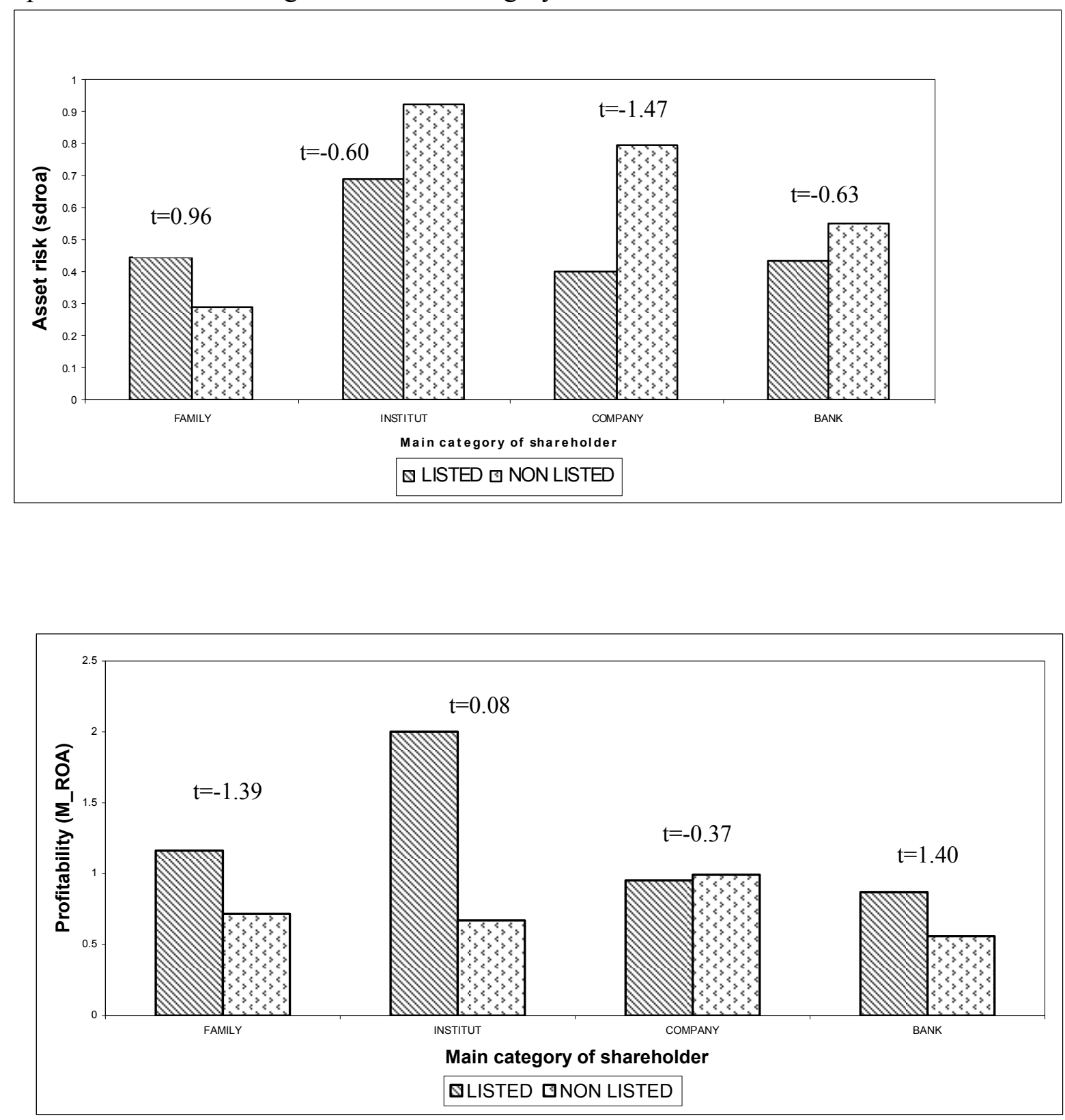

Note: We use the mode to determine the main category of shareholder of each bank; $t$ represents the T-statistic of the bilateral mean test between listed and non-listed banks for banks with the same main category of shareholder. ***, ** and * indicate significance at the $1 \%, 5 \%$ and $10 \%$ levels respectively. We consider five categories of owners: (i) managers/directors (MANAGER); (ii) non-financial companies (COMPANY); (iii) individual/family investors (FAMILY); (iv) banks (BANK); and (v) institutional investors - insurance company, financial companies and mutual \& pension funds (INSTITUT). 
Figure 1. (continue) Asset risk, default risk, profitability and asset growth rate for public and private banks according to their main category of shareholder
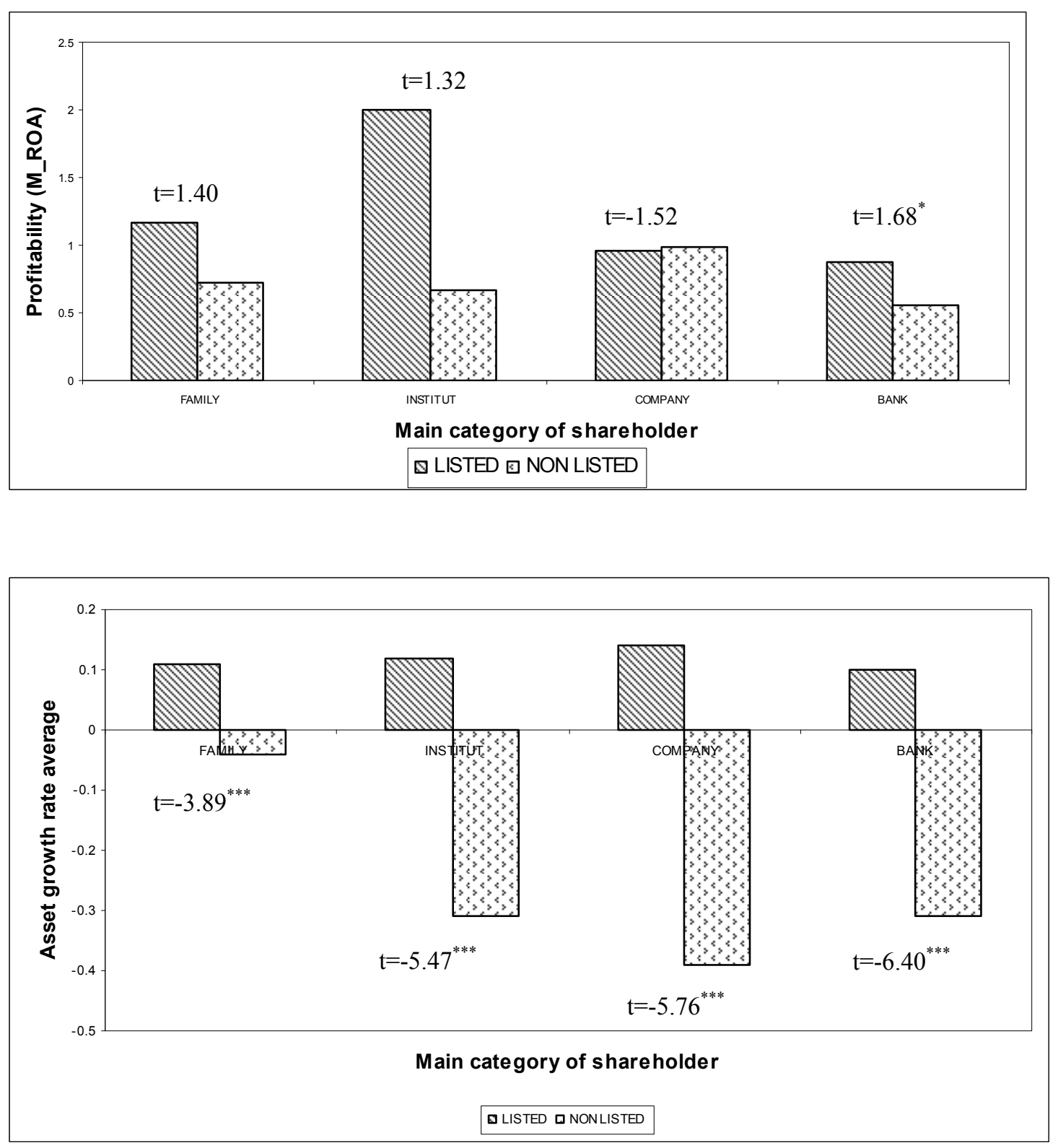

Note: We use the mode to determine the main category of shareholder of each bank; $t$ represents the T-statistic of the bilateral mean test between listed and non-listed banks for banks with the same main category of shareholder. ***,** and * indicate significance at the $1 \%, 5 \%$ and $10 \%$ levels respectively. We consider five categories of owners: (i) managers/directors (MANAGER); (ii) non-financial companies (COMPANY); (iii) individual/family investors (FAMILY); (iv) banks (BANK); and (v) institutional investors - insurance company, financial companies and mutual \& pension funds (INSTITUT). 


\section{References}

Acker, L., Athanassakos, G., 2003. A simultaneous equations analysis of analysts' forecast bias, analyst following and institutional ownership. Journal of Business Finance and Accounting, 30, 1017-1042.

Aghion, Ph., Tirole, J., 1997. Formal and real authority in organizations. Journal of Political Economy, 55, 1-27.

Anderson, R.C, Fraser, D.R, 2000. Corporate Control, Bank Risk Taking, and the Health of the Banking Industry. Journal of Banking and Finance, 24, 1383-1398.

Berger A., Clarke, G., Cill R., Klapper, L., Udell G., 2005. Corporate governance and bank performance: A joint analysis of the static, selection, and dynamic effects of domestic, foreign, and state ownership. Journal of Banking and Finance, 29, 21792221.

Bliss, R., Flannery, M., 2002. Market discipline in the governance of U.S. Bank Holding Companies: monitoring vs. influencing. European Finance Review, 6 (3), 361-395.

Bonin, J.P., Hasan, I., Wachtel, P., 2005. Bank performance, efficiency and ownership in transition countries. Journal of Banking and Finance, 29, 31-54.

Boubakri, N., Cosset, J.C., Fischer K., Guedhami O., 2005. Privatization and Bank Performance in developing countries. Journal of Banking and Finance, 29, 20152041.

Boyd, J.H., Graham, S.L, 1986. Risk, Regulation and Bank Holding Company Expansion. Quaterly Review, Federal Reserve Bank of Mineapolis.

Burkart, M., Gromb, D., Panunzi, F., 1997. Large shareholders, monitoring and the value of the firm. Quaterly Journal of Economics, 112, 693-728.

Chen, C.R., Steiner,T.L, Whyte, A.M, 1998. Risk-taking Behavior and Management Ownership in Depository Institutions. Journal of Financial Research, 21,1-16.

Claessens, S., Demirguc-kunt, A., Huizinga, H., 2001. How does foreign entry affect the domestic banking market? Journal of Banking and Finance, 25, 891-911.

Demsetz, H., Lehn, K, 1985. The Structure of Corporate Ownership: Causes and Consequences. Journal of Political Economics, 93, 1155-1177.

Esty, B., 1998. The impact of Contingent Liability on Commercial Bank Risk Taking. Journal of Financial Economics, 47, 189-218.

Flannery, M. J., 2001. The faces of market discipline, Journal of Financial Services Research, 20(2-3), 107-119. 
Galai, D., Masulis, R., 1976. The Option Pricing Model and the Risk Factor of Stock. Journal

of Financial Economics, 3 ,53-81.

Givoly, D., Hayn, C., Katz, S., Does public ownership of equity improve earnings quality? Accounting Review, Forthcoming.

Gorton, G., Rosen, R.,1995. Corporate Control, Portfolio Choice, and the Decline of Banking. Journal of Finance, 50, 509-527.

Goyeau, D., Tarazi A., 1992. Evaluation du risqué de défaillance bancaire en Europe. Revue d'Economie Politique, 102, 249-280.

Gugler, K., Weigland, J., 2003. Is ownership endogenous?, Applied Economics Letters, 10, 483-486.

Heckman, J., 1979. Sample selection bias as a specification error. Econometrica, 47, $153-161$.

Himmelberg, C., Hubbard, R., Palia, D, 1999. Understanding the determinants of managerial ownership and the link between ownership and performance, Journal of Financial Economics, 53, 353-384.

Iannota, G., Giacomo, N., Sironi, A., 2007. Ownership Structure, Risk and Performance in the European Banking Industry. Journal of Banking and Finance, 31, 2127-2149.

James, H., 1999. Owner as manager, extended horizon and the family firm. International Journal of the Economics of Business, 6, 41-56

Jensen, M.C., Meckling, W.H., 1976. Theory of the firm: Managerial behavior, Agency cost and Ownership structure. Journal of Financial Economics, 3, 305-360.

Knopf, J.K., Teal, J., 1996. Risk-taking behavior in the U.S thrift industry: ownership structure and regulatory changes. Journal of Banking and Finance, 1, 3-11.

Kwan, HK., 2004. Risk and Return of Publicly held versus Privately Owned banks. FRBNY Economic Policy Review.

Laeven, L., 1999. Risk and efficiency in East Asian banks. World Bank Discussion Paper $n^{\circ} 2255$.

La Porta, R., Lopez-de-Silanes, F., Shleifer, A., Vishny, R., 1999. Corporate ownership around the world. Journal of Finance, 54, 471-517.

La Porta, R., Lopez-de-Silanes, F., Shleifer, A., Vishny, R., 1998. Law and Finance, Journal of Political Economy, 106(6), 1113,-1155. 
Lepetit, L., Nys, E., Rous, P., Tarazi, A., 2008. Bank Income Structure and Risk: An Empirical Analysis of European Banks, Journal of Banking and Finance, 32, 14521467.

Micco,A., Ugo, P., Monica, Y., 2007. Bank ownership and performance: Does politics matter? Journal of Banking and Finance, 31, 219-241.

Morck, R., Stangeland, D., Yeung, B., 2000. Inherited wealth, corporate control, and economic growth: The Canadian disease, in: Morck, R. (Ed.), Concentrated Corporate Ownership, National Bureau of Economic Research Conference Volume, University of Chicago Press.

Nichols, D., Wahlen, J., Wieland, M., 2009. Publicly-traded versus privately-held: implications for conditional conservatism in bank accounting. Review of Accounting Studies, 14(1), 88-122.

Pound J., 1988. Proxy contests and the efficiency of shareholder oversight. Journal of Financial Economics, 10, 53-83

Saunders, A., Strock, E., Travlos, N., 1990. Ownership Structure, Deregulation, and Bank Risk Taking. Journal of Finance, 45(2), 643-654.

Shleifer A., 1998. State versus private ownership. Journal of Economic Perspective, $12,133-150$.

Shleifer A., Vishny R.W., 1998. The grabbing hand: government pathologies and their cures, Harvard University Press, MA.

Shleifer A., Vishny R.W., 1997. A survey of corporate governance. Journal of Finance, 52, 737-783.

Shleifer, A., Vishny, R., 1986. Large Shareholders and Corporate Control. Journal of Political Economy, 94, 461-488.

Stein, JC., 1989. Efficient capital markets, inefficient firms: A model of myopic corporate behavior. Quarterly Journal of Economics, 104, 655-669.

Stein, JC., 1988 .Takeover threats and managerial myopia. Journal of Political Economy, 96, 61-68.

Sullivan, R., Spong, K.R, 2007. Managerial Wealth, Ownership Structure, and Risk in Commercial Banks. Journal of Financial Intermediation, 16, 229-248.

Williams, J., Nguyen, N., 2005. Financial liberalization, crisis, and restructuring: A comparative study of bank performance and bank governance in South East Asia. Journal of Banking and Finance, 29, 2119-2154. 


\section{Appendix 1}

Table A1 Distribution per country of the number of banks for which the ownership variables are different from zero and the percentage of stock held by the different categories of owners

\begin{tabular}{|c|c|c|c|c|c|}
\hline & MANAGER & FAMILY & INSTITUT & COMPANY & BANK \\
\hline Austria & $\begin{array}{c}0 \\
(0,00)\end{array}$ & $\begin{array}{c}0 \\
(0,00) \\
\end{array}$ & $\begin{array}{c}2 \\
(87,00) \\
\end{array}$ & $\begin{array}{c}5 \\
(60,73) \\
\end{array}$ & $\begin{array}{c}11 \\
(74.72) \\
\end{array}$ \\
\hline Belgium & $\begin{array}{c}1 \\
(16,48)\end{array}$ & $\begin{array}{c}1 \\
(37,71)\end{array}$ & $\begin{array}{c}1 \\
(100,00)\end{array}$ & $\begin{array}{c}2 \\
(64.37) \\
\end{array}$ & $\begin{array}{c}4 \\
(99.99) \\
\end{array}$ \\
\hline Denmark & $\begin{array}{c}2 \\
(5,60)\end{array}$ & $\begin{array}{c}4 \\
(6,22)\end{array}$ & $\begin{array}{c}8 \\
(19,55)\end{array}$ & $\begin{array}{c}4 \\
(12,02)\end{array}$ & $\begin{array}{c}6 \\
(36.56)\end{array}$ \\
\hline Finland & $\begin{array}{c}0 \\
(0,00) \\
\end{array}$ & $\begin{array}{c}1 \\
(10,44) \\
\end{array}$ & $\begin{array}{c}2 \\
(21,84) \\
\end{array}$ & $\begin{array}{c}2 \\
(7,15) \\
\end{array}$ & $\begin{array}{c}2 \\
(29.50) \\
\end{array}$ \\
\hline France & $\begin{array}{c}2 \\
(3,36) \\
\end{array}$ & $\begin{array}{c}1 \\
(0,07) \\
\end{array}$ & $\begin{array}{c}7 \\
(37,23) \\
\end{array}$ & $\begin{array}{c}16 \\
(48,89) \\
\end{array}$ & $\begin{array}{c}57 \\
(88.94) \\
\end{array}$ \\
\hline Germany & $\begin{array}{c}1 \\
(2,00) \\
\end{array}$ & $\begin{array}{c}2 \\
(60,66) \\
\end{array}$ & $\begin{array}{c}6 \\
(86,09) \\
\end{array}$ & $\begin{array}{c}8 \\
(77,82) \\
\end{array}$ & $\begin{array}{c}25 \\
(92.94) \\
\end{array}$ \\
\hline Greece & $\begin{array}{c}1 \\
(5,96)\end{array}$ & $\begin{array}{c}2 \\
(12,94)\end{array}$ & $\begin{array}{c}3 \\
(28,57)\end{array}$ & $\begin{array}{c}2 \\
(29,97)\end{array}$ & $\begin{array}{c}2 \\
(13.89)\end{array}$ \\
\hline Irland & $\begin{array}{c}0 \\
(0,00)\end{array}$ & $\begin{array}{c}0 \\
(0,00)\end{array}$ & $\begin{array}{c}2 \\
(15,80)\end{array}$ & $\begin{array}{c}4 \\
(6.84)\end{array}$ & $\begin{array}{c}2 \\
(55.55)\end{array}$ \\
\hline Italy & $\begin{array}{c}0 \\
(0,00) \\
\end{array}$ & $\begin{array}{c}5 \\
(3,23) \\
\end{array}$ & $\begin{array}{c}7 \\
(15,55) \\
\end{array}$ & $\begin{array}{c}10 \\
(23.62) \\
\end{array}$ & $\begin{array}{c}14 \\
(61.92) \\
\end{array}$ \\
\hline Luxembourg & $\begin{array}{c}0 \\
(0,00)\end{array}$ & $\begin{array}{c}1 \\
(66,87)\end{array}$ & $\begin{array}{c}4 \\
(51,66)\end{array}$ & $\begin{array}{c}3 \\
(66.70)\end{array}$ & $\begin{array}{c}28 \\
(98.53) \\
\end{array}$ \\
\hline Netherlands & $\begin{array}{c}0 \\
(0,00) \\
\end{array}$ & $\begin{array}{c}0 \\
(0,00) \\
\end{array}$ & $\begin{array}{c}0 \\
(0,00) \\
\end{array}$ & $\begin{array}{c}1 \\
(10.20) \\
\end{array}$ & $\begin{array}{c}7 \\
(87.60) \\
\end{array}$ \\
\hline Portugal & $\begin{array}{c}0 \\
(0,00)\end{array}$ & $\begin{array}{c}0 \\
(0,00)\end{array}$ & $\begin{array}{c}2 \\
(32,76)\end{array}$ & $\begin{array}{c}1 \\
(15.94)\end{array}$ & $\begin{array}{c}1 \\
(16.41)\end{array}$ \\
\hline Spain & $\begin{array}{c}1 \\
(33,72) \\
\end{array}$ & $\begin{array}{c}4 \\
(17,51) \\
\end{array}$ & $\begin{array}{c}6 \\
(21,50) \\
\end{array}$ & $\begin{array}{c}11 \\
(14.54) \\
\end{array}$ & $\begin{array}{c}12 \\
(53.68) \\
\end{array}$ \\
\hline Sweden & $\begin{array}{c}0 \\
(0,00) \\
\end{array}$ & $\begin{array}{c}0 \\
(0,00) \\
\end{array}$ & $\begin{array}{c}2 \\
(14,54) \\
\end{array}$ & $\begin{array}{c}2 \\
(17.29) \\
\end{array}$ & $\begin{array}{c}0 \\
(0,00) \\
\end{array}$ \\
\hline Switzerland & $\begin{array}{c}0 \\
(0,00) \\
\end{array}$ & $\begin{array}{c}2 \\
15,77 \\
\end{array}$ & $\begin{array}{c}0 \\
(0,00) \\
\end{array}$ & $\begin{array}{c}3 \\
(66.18) \\
\end{array}$ & $\begin{array}{c}1 \\
(69.00) \\
\end{array}$ \\
\hline United Kingdom & $\begin{array}{c}0 \\
(0,00)\end{array}$ & $\begin{array}{c}2 \\
(50.14)\end{array}$ & $\begin{array}{c}3 \\
(15,00)\end{array}$ & $\begin{array}{c}4 \\
(60.60)\end{array}$ & $\begin{array}{c}8 \\
(83.62) \\
\end{array}$ \\
\hline Total & 8 & 25 & 55 & 78 & 180 \\
\hline
\end{tabular}

For each country, the first line indicates the number of banks for which the ownership variables are different from zero, and the second line, in brackets, indicates the percentage of stock held by the different categories of owners.

For example, in Belgium, we have 1 bank in which managers/directors hold equity, and these managers/directors hold on average 16.48 of the total equity. 
Table A2. Descriptive statistics of the ownership variables for the large sample of 905 banks for which Bankscope Fitch IBCA provide information on the ownership structure in 2005

\begin{tabular}{|l|cc|cc|cc|cc|cc|}
\cline { 2 - 11 } \multicolumn{1}{c|}{} & \multicolumn{2}{c|}{ MANAGER $^{\mathrm{a}}$} & \multicolumn{2}{c|}{ FAMILY } & \multicolumn{2}{c|}{ INSTITUT } & \multicolumn{2}{c|}{ COMPANY } & \multicolumn{2}{c|}{ BANK } \\
\cline { 2 - 12 } \multicolumn{1}{c|}{} & $=0$ & $>0$ & $=0$ & $>0$ & $=0$ & $>0$ & $=0$ & $>0$ & $=0$ & $>0$ \\
\hline $\begin{array}{l}\text { Number of } \\
\text { banks }\end{array}$ & $\begin{array}{c}891 \\
(98.46)\end{array}$ & $\begin{array}{c}14 \\
(1.54)\end{array}$ & $\begin{array}{c}845 \\
(93.38)\end{array}$ & $\begin{array}{c}60 \\
(6.62)\end{array}$ & $\begin{array}{c}724 \\
(80)\end{array}$ & $\begin{array}{c}181 \\
(20)\end{array}$ & $\begin{array}{c}649 \\
(71.72)\end{array}$ & $\begin{array}{c}256 \\
(28.28)\end{array}$ & $\begin{array}{c}289 \\
(31.94)\end{array}$ & $\begin{array}{c}616 \\
(68.06)\end{array}$ \\
\hline $\begin{array}{l}\text { Percentage } \\
\text { of equity }\end{array}$ & 0 & 0.192 & 0 & 2.769 & 0 & 9.664 & 0 & 18.097 & 0 & 62.316 \\
\hline
\end{tabular}

Five categories of owners are considered: (i) managers/directors (MANAGER); (ii) non-financial companies (COMPANY); (iii) individual/family investors (FAMILY); (iv) banks (BANK); and (v) institutional investors - insurance company, financial companies and mutual \& pension funds (INSTITUT).

${ }^{a}$ For example, in the broad sample, we have 891 banks for which managers do not hold equity and 14 banks for which managers do hold equity. We also present the percentage of banks for which the variable $M A N A G E R$ is not equal to zero $(1.54 \%)$ as well as the percentage of equity held on average by the 14 managers who hold a stake $(0.192 \%)$ 
Table A3. Influence of ownership structure and ownership dispersion on the risk-taking behavior of banks, cross-section OLS regressions

\begin{tabular}{|c|c|c|c|c|c|c|c|c|c|}
\hline & \multicolumn{3}{|c|}{ Risk measures } & \multicolumn{4}{|c|}{ Default Risk measures } & \multicolumn{2}{|c|}{ Profitability measures } \\
\hline & SDROA & SDROE & M LLP & Z & $\mathrm{ZP}$ & ZP1 & $\mathrm{ZP} 2$ & M_ROA & M ROE \\
\hline CONSTANT & $\begin{array}{c}-0.0284 \\
(-0.04)\end{array}$ & $\begin{array}{l}-6.519 \\
(-0.54)\end{array}$ & $\begin{array}{l}3.489^{*} \\
(1.80)\end{array}$ & $\begin{array}{l}38.28 \\
(1.21)\end{array}$ & $\begin{array}{l}15.27 \\
(0.33)\end{array}$ & $\begin{array}{l}-2.848 \\
(-0.47)\end{array}$ & $\begin{array}{l}18.12 \\
(0.44)\end{array}$ & $\begin{array}{c}2.814^{* * * *} \\
(3.43)\end{array}$ & $\begin{array}{c}23.05^{* * *} \\
(3.14)\end{array}$ \\
\hline MANAGER & $\begin{array}{l}0.674^{\text {**** }} \\
(15.55)\end{array}$ & $\begin{array}{c}7.696^{* * *} \\
(11.48)\end{array}$ & $\begin{array}{c}0.0000831 \\
(0.00)\end{array}$ & $\begin{array}{l}-2.400 \\
(-1.35) \\
\end{array}$ & $\begin{array}{l}-3.674 \\
(-1.52)\end{array}$ & $\begin{array}{l}-0.535^{*} \\
(-1.97)\end{array}$ & $\begin{array}{l}-3.139 \\
(-1.44)\end{array}$ & $\begin{array}{l}0.114^{*} \\
(1.67)\end{array}$ & $\begin{array}{l}0.414 \\
(0.43)\end{array}$ \\
\hline FAMILY & $\begin{array}{c}-0.00179 \\
(-0.52)\end{array}$ & $\begin{array}{c}-0.0565 \\
(-1.47)\end{array}$ & $\begin{array}{c}-0.0162^{* *} \\
(-2.05)\end{array}$ & $\begin{array}{c}-0.0223 \\
(-0.04)\end{array}$ & $\begin{array}{l}-0.241 \\
(-0.51)\end{array}$ & $\begin{array}{c}-0.0343 \\
(-0.86)\end{array}$ & $\begin{array}{l}-0.207 \\
(-0.48)\end{array}$ & $\begin{array}{c}-0.00384 \\
(-0.61)\end{array}$ & $\begin{array}{c}-0.0402 \\
(-1.03)\end{array}$ \\
\hline COMPANY & $\begin{array}{c}0.00228 \\
(0.54)\end{array}$ & $\begin{array}{r}-0.0357 \\
(-0.47)\end{array}$ & $\begin{array}{c}-0.0152 \\
(-1.37)\end{array}$ & $\begin{array}{c}0.0743 \\
(0.22)\end{array}$ & $\begin{array}{c}-0.0171 \\
(-0.06)\end{array}$ & $\begin{array}{c}0.0148 \\
(0.47)\end{array}$ & $\begin{array}{c}-0.0319 \\
(-0.13)\end{array}$ & $\begin{array}{c}-0.00589 \\
(-0.82)\end{array}$ & $\begin{array}{c}0.0121 \\
(0.25)\end{array}$ \\
\hline BANK & $\begin{array}{c}-0.00583^{* *} \\
(-2.11)\end{array}$ & $\begin{array}{c}-0.0688^{*} \\
(-1.71)\end{array}$ & $\begin{array}{c}-0.00348 \\
(-0.31)\end{array}$ & $\begin{array}{l}0.935 \\
(1.60)\end{array}$ & $\begin{array}{l}0.593 \\
(1.01)\end{array}$ & $\begin{array}{c}-0.00322 \\
(-0.16)\end{array}$ & $\begin{array}{l}0.597 \\
(1.02)\end{array}$ & $\begin{array}{c}-0.00307 \\
(-0.91)\end{array}$ & $\begin{array}{c}-0.0474 \\
(-1.19)\end{array}$ \\
\hline MANAGER*HERF_MANAGER & $\begin{array}{c}-0.677^{* * *} \\
(-14.97)\end{array}$ & $\begin{array}{c}-7.768^{* * *} \\
(-10.86)\end{array}$ & $\begin{array}{c}-0.0271 \\
(-0.38)\end{array}$ & $\begin{array}{l}1.591 \\
(0.76)\end{array}$ & $\begin{array}{l}3.116 \\
(1.20)\end{array}$ & $\begin{array}{l}0.460 \\
(1.54)\end{array}$ & $\begin{array}{l}2.656 \\
(1.13)\end{array}$ & $\begin{array}{c}-0.0917 \\
(-1.30)\end{array}$ & $\begin{array}{l}-0.133 \\
(-0.14)\end{array}$ \\
\hline FAMILY*HERF_FAMILY & $\begin{array}{c}-0.00565 \\
(-0.70)\end{array}$ & $\begin{array}{c}-0.0424 \\
(-0.46)\end{array}$ & $\begin{array}{c}-0.00299 \\
(-0.22)\end{array}$ & $\begin{array}{l}0.895 \\
(0.61)\end{array}$ & $\begin{array}{l}0.784 \\
(0.81)\end{array}$ & $\begin{array}{c}0.0610 \\
(0.76)\end{array}$ & $\begin{array}{l}0.723 \\
(0.81)\end{array}$ & $\begin{array}{c}0.00681 \\
(0.53)\end{array}$ & $\begin{array}{c}0.0896 \\
(0.90)\end{array}$ \\
\hline COMPANY*HERF_COMPANY & $\begin{array}{c}-0.00572 \\
(-1.10)\end{array}$ & $\begin{array}{c}0.0819 \\
(0.57)\end{array}$ & $\begin{array}{c}0.00616 \\
(0.48)\end{array}$ & $\begin{array}{l}0.128 \\
(0.34)\end{array}$ & $\begin{array}{c}0.0168 \\
(0.05)\end{array}$ & $\begin{array}{c}-0.0330 \\
(-0.86)\end{array}$ & $\begin{array}{c}0.0497 \\
(0.16)\end{array}$ & $\begin{array}{c}0.00444 \\
(0.54)\end{array}$ & $\begin{array}{c}-0.0163 \\
(-0.23)\end{array}$ \\
\hline BANK*HERF_BANK & $\begin{array}{c}0.00443^{*} \\
(1.92)\end{array}$ & $\begin{array}{c}0.0444 \\
(1.33)\end{array}$ & $\begin{array}{c}-0.00881 \\
(-0.90)\end{array}$ & $\begin{array}{l}-0.726 \\
(-1.19)\end{array}$ & $\begin{array}{l}-0.513 \\
(-0.80)\end{array}$ & $\begin{array}{c}0.000431 \\
(0.02)\end{array}$ & $\begin{array}{l}-0.514 \\
(-0.81)\end{array}$ & $\begin{array}{c}0.00229 \\
(0.79)\end{array}$ & $\begin{array}{c}0.0424 \\
(1.29)\end{array}$ \\
\hline M_LNTA & $\begin{array}{c}0.0638^{*} \\
(1.87)\end{array}$ & $\begin{array}{l}1.135^{*} \\
(1.88)\end{array}$ & $\begin{array}{l}-0.110 \\
(-1.19)\end{array}$ & $\begin{array}{c}-3.932^{* *} \\
(-2.14)\end{array}$ & $\begin{array}{l}-3.274 \\
(-1.06)\end{array}$ & $\begin{array}{c}0.104 \\
(0.35)\end{array}$ & $\begin{array}{l}-3.378 \\
(-1.16)\end{array}$ & $\begin{array}{c}-0.0933^{* *} \\
(-2.14)\end{array}$ & $\begin{array}{l}-0.359 \\
(-1.09)\end{array}$ \\
\hline M_OEQUITY & $\begin{array}{c}0.0656^{* * *} \\
(6.64)\end{array}$ & $\begin{array}{c}-0.0148 \\
(-0.15)\end{array}$ & $\begin{array}{c}-0.0553^{* *} \\
(-2.07)\end{array}$ & $\begin{array}{l}-0.182 \\
(-0.43)\end{array}$ & $\begin{array}{l}-0.833 \\
(-1.38)\end{array}$ & $\begin{array}{l}-0.100 \\
(-1.63)\end{array}$ & $\begin{array}{l}-0.733 \\
(-1.30)\end{array}$ & $\begin{array}{c}0.0454^{* *} \\
(2.44)\end{array}$ & $\begin{array}{l}-0.132 \\
(-1.38) \\
\end{array}$ \\
\hline M_DEPOSIT & $\begin{array}{c}-0.00167 \\
(-0.81)\end{array}$ & $\begin{array}{c}0.000154 \\
(0.00)\end{array}$ & $\begin{array}{c}-0.0130 \\
(-1.44)\end{array}$ & $\begin{array}{c}0.0389 \\
(0.27) \\
\end{array}$ & $\begin{array}{c}0.00860 \\
(0.03)\end{array}$ & $\begin{array}{c}-0.0652^{* * *} \\
(-2.73)\end{array}$ & $\begin{array}{c}0.0738 \\
(0.30)\end{array}$ & $\begin{array}{c}-0.00638^{* *} \\
(-2.04)\end{array}$ & $\begin{array}{c}-0.0924^{* * *} \\
(-3.14)\end{array}$ \\
\hline LISTED & $\begin{array}{l}0.229 \\
(0.50)\end{array}$ & $\begin{array}{l}4.484 \\
(0.80)\end{array}$ & $\begin{array}{l}-0.367 \\
(-0.48)\end{array}$ & $\begin{array}{l}8.779 \\
(0.43)\end{array}$ & $\begin{array}{l}32.71 \\
(1.04)\end{array}$ & $\begin{array}{l}8.985^{*} \\
(1.93)\end{array}$ & $\begin{array}{l}23.73 \\
(0.87)\end{array}$ & $\begin{array}{l}-0.433 \\
(-1.03)\end{array}$ & $\begin{array}{l}0.891 \\
(0.20)\end{array}$ \\
\hline LAMBDA & $\begin{array}{c}0.0505 \\
(1.09) \\
\end{array}$ & $\begin{array}{l}1.242 \\
(1.47)\end{array}$ & $\begin{array}{l}-0.120 \\
(-0.58)\end{array}$ & $\begin{array}{l}0.439 \\
(0.14)\end{array}$ & $\begin{array}{l}6.170 \\
(1.27)\end{array}$ & $\begin{array}{c}0.0529 \\
(0.14)\end{array}$ & $\begin{array}{l}6.117 \\
(1.32)\end{array}$ & $\begin{array}{c}-0.177^{* * *} \\
(-2.73)\end{array}$ & $\begin{array}{c}-2.047^{* * *} \\
(-3.06)\end{array}$ \\
\hline LAMBDA*LISTED & $\begin{array}{l}-0.174 \\
(-0.48)\end{array}$ & $\begin{array}{l}-3.660 \\
(-0.76)\end{array}$ & $\begin{array}{l}-0.130 \\
(-0.35)\end{array}$ & $\begin{array}{l}-0.525 \\
(-0.04)\end{array}$ & $\begin{array}{l}-18.29 \\
(-0.81)\end{array}$ & $\begin{array}{l}-5.978^{*} \\
(-1.78)\end{array}$ & $\begin{array}{l}-12.31 \\
(-0.62)\end{array}$ & $\begin{array}{l}0.168 \\
(0.44)\end{array}$ & $\begin{array}{l}-1.699 \\
(-0.54)\end{array}$ \\
\hline COUNTRY DUMMIES & Yes & Yes & Yes & Yes & Yes & Yes & Yes & Yes & Yes \\
\hline Number of obs. & 244 & 244 & 241 & 242 & 244 & 244 & 244 & 244 & 243 \\
\hline R2 & 0.313 & 0.0960 & 0.108 & 0.148 & 0.0644 & 0.154 & 0.0623 & 0.306 & 0.231 \\
\hline
\end{tabular}

$* * *, * *$ and * indicate significance, respectively, at the $1 \%, 5 \%$ and $10 \%$ levels respectively. t-statistics are corrected for heteroskedasticity following White's methodology.

Variable definitions (standard deviations and means are computed over the period 1999-2005): $S D R O A=$ standard deviation of the return on average assets; $S D R O E=$ standard deviation of the return on average equity , $M_{-} L L P=$ mean of the ratio of loan loss provisions to net loans; $Z=Z$-score; $Z P=Z \mathrm{P}$-score; $Z P I=$ measure of bank portfolio risk; $Z P 2=$ measure of leverage risk; $M \_R O A=$ mean of the return on average asset; $M_{-} R O E=$ mean of the return on average equity; $M_{-} L N T A=$ mean of the natural logarithm of total asset; $M_{-} O E Q U I T Y=$ mean of the ratio of equity to total assets orthogonalized with TA; $M_{-} D E P O S I T=$ mean of the ratio of deposits to total assets; LISTED = a dummy variable which takes the value of one if the bank is listed on the stock market and zero

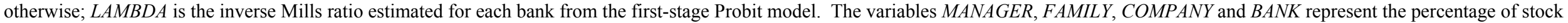
held respectively by managers/directors, families/individuals, non-financial companies and banks. HERF_ $J$ represents the Herfindahl index computed to measure the ownership dispersion for the category of shareholder $\mathrm{J}$ (see Table 6 for a definition). We also include dummy variables to account for country specific effects. 
Table A4: Influence of ownership structure on the risk-taking behavior and profitability of large banks (Model 1), cross-section OLS regressions

\begin{tabular}{|c|c|c|c|c|c|c|c|c|c|}
\hline & \multicolumn{3}{|c|}{ Risk measures } & \multicolumn{4}{|c|}{ Default Risk measures } & \multicolumn{2}{|c|}{ Profitability measures } \\
\hline & SDROA & SDROE & M LLP & $\mathrm{Z}$ & $\mathrm{ZP}$ & ZP1 & $\mathrm{ZP} 2$ & M ROA & M ROE \\
\hline CONSTANT & $\begin{array}{l}0.300 \\
(0.29)\end{array}$ & $\begin{array}{l}3.445 \\
(0.19)\end{array}$ & $\begin{array}{l}0.181 \\
(0.07)\end{array}$ & $\begin{array}{l}4.822 \\
(0.13)\end{array}$ & $\begin{array}{l}-24.90 \\
(-0.44)\end{array}$ & $\begin{array}{l}-2.520 \\
(-0.29)\end{array}$ & $\begin{array}{l}-22.38 \\
(-0.47)\end{array}$ & $\begin{array}{c}3.445^{* * *} \\
(3.55)\end{array}$ & $\begin{array}{c}43.79^{* * * *} \\
(4.29)\end{array}$ \\
\hline FAMILY & $\begin{array}{c}-0.00592^{*} \\
(-1.93)\end{array}$ & $\begin{array}{c}-0.125^{* *} \\
(-2.25)\end{array}$ & $\begin{array}{c}-0.00219 \\
(-0.36)\end{array}$ & $\begin{array}{c}0.741^{* * *} \\
(2.76)\end{array}$ & $\begin{array}{r}0.0199 \\
(0.07)\end{array}$ & $\begin{array}{c}-0.0345 \\
(-0.78)\end{array}$ & $\begin{array}{c}0.0544 \\
(0.23)\end{array}$ & $\begin{array}{c}-0.00182 \\
(-0.56)\end{array}$ & $\begin{array}{c}-0.0719^{*} \\
(-1.96)\end{array}$ \\
\hline COMPANY & $\begin{array}{c}-0.000298 \\
(-0.09)\end{array}$ & $\begin{array}{c}0.0875 \\
(0.73)\end{array}$ & $\begin{array}{c}0.00434 \\
(0.62)\end{array}$ & $\begin{array}{l}0.281 \\
(1.41)\end{array}$ & $\begin{array}{l}-0.288 \\
(-1.43)\end{array}$ & $\begin{array}{c}-0.0383 \\
(-1.20)\end{array}$ & $\begin{array}{l}-0.250 \\
(-1.46)\end{array}$ & $\begin{array}{c}-0.00450 \\
(-0.98)\end{array}$ & $\begin{array}{l}-0.0606 \\
(-0.90)\end{array}$ \\
\hline BANK & $\begin{array}{c}-0.00196 \\
(-1.38)\end{array}$ & $\begin{array}{r}-0.0387 \\
(-1.08)\end{array}$ & $\begin{array}{c}0.000536 \\
(0.18)\end{array}$ & $\begin{array}{c}0.538^{* *} \\
(2.28)\end{array}$ & $\begin{array}{c}-0.0881 \\
(-0.42)\end{array}$ & $\begin{array}{c}-0.0283 \\
(-0.78)\end{array}$ & $\begin{array}{c}-0.0598 \\
(-0.34)\end{array}$ & $\begin{array}{c}-0.00235 \\
(-1.08)\end{array}$ & $\begin{array}{c}-0.0693^{* * *} \\
(-2.85)\end{array}$ \\
\hline M_LNTA & $\begin{array}{c}(-1.044) \\
(0.88)\end{array}$ & $\begin{array}{c}(-1.00) \\
0.601 \\
(0.70)\end{array}$ & $\begin{array}{c}0.0516 \\
(0.44)\end{array}$ & $\begin{array}{l}-2.953 \\
(-1.35)\end{array}$ & $\begin{array}{l}(-0.42) \\
-0.329 \\
(-0.11)\end{array}$ & $\begin{array}{c}-0.0668 \\
(-0.16)\end{array}$ & $\begin{array}{l}-0.262 \\
(-0.11)\end{array}$ & $\begin{array}{c}-0.114^{* *} \\
(-2.37)\end{array}$ & $\begin{array}{c}-1.342^{* * *} \\
(-2.68)\end{array}$ \\
\hline M_OEQUITY & $\begin{array}{c}0.0564^{* * *} \\
(4.55)\end{array}$ & $\begin{array}{l}-0.162 \\
(-0.72)\end{array}$ & $\begin{array}{c}-0.0579^{* * *} \\
(-2.85)\end{array}$ & $\begin{array}{l}0.349 \\
(0.63)\end{array}$ & $\begin{array}{l}0.275 \\
(0.30)\end{array}$ & $\begin{array}{c}-0.0262 \\
(-0.21)\end{array}$ & $\begin{array}{c}0.302 \\
(0.38)\end{array}$ & $\begin{array}{c}0.0570^{* * *} \\
(4.43)\end{array}$ & $\begin{array}{c}-0.0766 \\
(-0.47)\end{array}$ \\
\hline M_DEPOSIT & $\begin{array}{c}-0.00190 \\
(-0.57)\end{array}$ & $\begin{array}{c}-0.0306 \\
(-0.47)\end{array}$ & $\begin{array}{c}-0.00728 \\
(-0.49)\end{array}$ & $\begin{array}{c}0.0763 \\
(0.43)\end{array}$ & $\begin{array}{l}-0.143 \\
(-0.61)\end{array}$ & $\begin{array}{c}-0.0625^{* *} \\
(-2.04)\end{array}$ & $\begin{array}{c}-0.0808 \\
(-0.38)\end{array}$ & $\begin{array}{c}-0.00662^{* *} \\
(-2.21)\end{array}$ & $\begin{array}{c}-0.118^{* * *} \\
(-3.00)\end{array}$ \\
\hline LISTED & $\begin{array}{l}0.338 \\
(0.59)\end{array}$ & $\begin{array}{l}3.985 \\
(0.49)\end{array}$ & $\begin{array}{l}0.807 \\
(0.67)\end{array}$ & $\begin{array}{l}25.76 \\
(1.20)\end{array}$ & $\begin{array}{l}58.60 \\
(1.49)\end{array}$ & $\begin{array}{l}10.37 \\
(1.57)\end{array}$ & $\begin{array}{c}(-0.50) \\
48.24 \\
(1.46)\end{array}$ & $\begin{array}{l}-0.796 \\
(-1.54)\end{array}$ & $\begin{array}{l}(-3.00) \\
-7.725 \\
(-1.37)\end{array}$ \\
\hline LAMBDA & $\begin{array}{l}0.0813 \\
(1.21)\end{array}$ & $\begin{array}{l}2.532 \\
(1.62)\end{array}$ & $\begin{array}{c}0.0561 \\
(0.15)\end{array}$ & $\begin{array}{l}-3.217 \\
(-1.12)\end{array}$ & $\begin{array}{l}1.931 \\
(0.38)\end{array}$ & $\begin{array}{l}0.0378 \\
(0.05)\end{array}$ & $\begin{array}{r}1.893 \\
(0.43)\end{array}$ & $\begin{array}{c}-0.168^{* * * *} \\
(-2.64)\end{array}$ & $\begin{array}{c}-3.039^{* * * *} \\
(-3.21)\end{array}$ \\
\hline LAMBDA*LISTED & $\begin{array}{l}-0.274 \\
(-0.59)\end{array}$ & $\begin{array}{l}-3.839 \\
(-0.61)\end{array}$ & $\begin{array}{l}-0.447 \\
(-0.93)\end{array}$ & $\begin{array}{l}-0.919 \\
(-0.07)\end{array}$ & $\begin{array}{l}-36.27 \\
(-1.38)\end{array}$ & $\begin{array}{l}-7.058 \\
(-1.60)\end{array}$ & $\begin{array}{l}-29.21 \\
(-1.32)\end{array}$ & $\begin{array}{l}0.306 \\
(0.65)\end{array}$ & $\begin{array}{l}1.021 \\
(0.25)\end{array}$ \\
\hline COUNTRY DUMMIES & Yes & Yes & Yes & Yes & Yes & Yes & Yes & Yes & Yes \\
\hline Number of obs. & 151 & 151 & 150 & 150 & 151 & 151 & 151 & 151 & 150 \\
\hline R2 & 0.259 & 0.148 & 0.103 & 0.289 & 0.144 & 0.205 & 0.136 & 0.378 & 0.233 \\
\hline
\end{tabular}

$* * *, * *$ and $*$ indicate significance at the $1 \%, 5 \%$ and $10 \%$ levels respectively. t-statistics are corrected for heteroskedasticity following White's methodology. Variable definitions (standard deviations and means are computed over the period 1999-2005): SDROA= standard deviation of the return on average assets; $S D R O E=$ standard deviation of the return on average equity , $M_{-} L L P=$ mean of the ratio of loan loss provisions to net loans; $Z=Z$-score; $Z P=Z \mathrm{P}$-score; $Z P 1=$ measure of bank portfolio risk; $Z P 2=$ measure of leverage risk; $M \_R O A=$ mean of the return on average asset; $M \_R O E=$ mean of the return on average equity; $M L N T A=$ mean of the natural logarithm of total asset; $M O E O U I T Y=$ mean of the ratio of equity to total assets orthogonalized with TA; $M$ DEPOSIT = mean of the ratio of deposits to total assets; $L I S T E D=$ a dummy variable which takes the value of one if the bank is listed on the stock market and zero otherwise; $L A M B D A$ is the inverse Mills ratio estimated for each bank from the first-stage Probit model. The variables FAMILY, COMPANY and BANK represent the percentage of stock held respectively by families/individuals, non-financial companies and banks. We also include dummy variables to account for country specific effects. 
Table A5 Influence of ownership structure on the risk-taking behavior and profitability of small banks (Model 1), cross-section OLS regressions

\begin{tabular}{|c|c|c|c|c|c|c|c|c|c|}
\hline & \multicolumn{3}{|c|}{ Risk measures } & \multicolumn{4}{|c|}{ Default Risk measures } & \multicolumn{2}{|c|}{ Profitability measures } \\
\hline & SDROA & SDROE & M_LLP & $\mathrm{Z}$ & ZP & $\mathrm{ZP} 1$ & $\mathrm{ZP} 2$ & M_ROA & M_ROE \\
\hline CONSTANT & $\begin{array}{l}2.171^{*} \\
(1.73)\end{array}$ & $\begin{array}{l}12.99 \\
(1.41)\end{array}$ & $\begin{array}{c}8.449^{* *} \\
(2.27)\end{array}$ & $\begin{array}{c}-226.3^{* * *} \\
(-3.13)\end{array}$ & $\begin{array}{c}-208.4^{* *} \\
(-2.62)\end{array}$ & $\begin{array}{c}-16.05^{* *} \\
(-2.19)\end{array}$ & $\begin{array}{c}-192.4^{* *} \\
(-2.58)\end{array}$ & $\begin{array}{l}2.126 \\
(1.12)\end{array}$ & $\begin{array}{l}5.490 \\
(0.42)\end{array}$ \\
\hline FAMILY & $\begin{array}{c}-0.0286^{* *} \\
(-2.61)\end{array}$ & $\begin{array}{c}-0.296^{* * *} \\
(-3.18)\end{array}$ & $\begin{array}{c}-0.0357 \\
(-0.97)\end{array}$ & $\begin{array}{c}5.077^{* * *} \\
(6.05)\end{array}$ & $\begin{array}{c}4.520^{* * *} \\
(5.86)\end{array}$ & $\begin{array}{c}0.344^{* * *} \\
(7.15)\end{array}$ & $\begin{array}{c}4.176^{* * *} \\
(5.62)\end{array}$ & $\begin{array}{c}0.0328^{* *} \\
(2.36)\end{array}$ & $\begin{array}{l}0.252^{* *} \\
(2.09)\end{array}$ \\
\hline COMPANY & $\begin{array}{c}-0.00914^{* *} \\
(-2.31)\end{array}$ & $\begin{array}{c}-0.0651^{* *} \\
(-2.37)\end{array}$ & $\begin{array}{c}-0.0203 \\
(-1.58)\end{array}$ & $\begin{array}{l}0.339 \\
(1.54)\end{array}$ & $\begin{array}{l}0.309 \\
(1.27)\end{array}$ & $\begin{array}{c}0.00116 \\
(0.08)\end{array}$ & $\begin{array}{c}0.308 \\
(1.30)\end{array}$ & $\begin{array}{c}0.00130 \\
(0.29)\end{array}$ & $\begin{array}{c}0.0338 \\
(1.00)\end{array}$ \\
\hline BANK & $\begin{array}{c}-0.00259 \\
(-0.78)\end{array}$ & $\begin{array}{c}-0.0374 \\
(-1.53)\end{array}$ & $\begin{array}{c}-0.0179 \\
(-1.52)\end{array}$ & $\begin{array}{l}0.0919 \\
(0.57)\end{array}$ & $\begin{array}{l}0.309 \\
(1.58)\end{array}$ & $\begin{array}{c}0.0241 \\
(1.42)\end{array}$ & $\begin{array}{l}0.285 \\
(1.54)\end{array}$ & $\begin{array}{c}0.000652 \\
(0.17)\end{array}$ & $\begin{array}{c}0.0306 \\
(0.91)\end{array}$ \\
\hline M_LNTA & $\begin{array}{c}0.00454 \\
(0.05)\end{array}$ & $\begin{array}{l}0.786 \\
(1.29)\end{array}$ & $\begin{array}{c}-0.372^{*} \\
(-1.74)\end{array}$ & $\begin{array}{l}-4.794 \\
(-0.80)\end{array}$ & $\begin{array}{l}-5.169 \\
(-0.73)\end{array}$ & $\begin{array}{l}-0.155 \\
(-0.25)\end{array}$ & $\begin{array}{l}-5.014 \\
(-0.74)\end{array}$ & $\begin{array}{l}-0.258^{*} \\
(-1.70)\end{array}$ & $\begin{array}{l}-0.779 \\
(-0.73)\end{array}$ \\
\hline M_OEQUITY & $\begin{array}{c}0.0679^{* * *} \\
(4.57)\end{array}$ & $\begin{array}{c}0.0612 \\
(0.98)\end{array}$ & $\begin{array}{c}-0.0723 \\
(-1.33)\end{array}$ & $\begin{array}{l}-0.589 \\
(-0.66)\end{array}$ & $\begin{array}{l}-2.073 \\
(-1.57)\end{array}$ & $\begin{array}{c}-0.150^{*} \\
(-1.70)\end{array}$ & $\begin{array}{l}-1.923 \\
(-1.49)\end{array}$ & $\begin{array}{c}0.0245 \\
(0.70)\end{array}$ & $\begin{array}{l}-0.190 \\
(-1.38)\end{array}$ \\
\hline M_DEPOSIT & $\begin{array}{c}-0.00468 \\
(-1.63) \\
\end{array}$ & $\begin{array}{c}-0.0286 \\
(-1.24)\end{array}$ & $\begin{array}{c}-0.0121 \\
(-1.11)\end{array}$ & $\begin{array}{l}0.532 \\
(1.23)\end{array}$ & $\begin{array}{l}0.753 \\
(1.15)\end{array}$ & $\begin{array}{c}-0.0633 \\
(-1.63)\end{array}$ & $\begin{array}{l}0.816 \\
(1.27)\end{array}$ & $\begin{array}{c}-0.00690 \\
(-1.18)\end{array}$ & $\begin{array}{c}-0.119^{* * *} \\
(-2.92)\end{array}$ \\
\hline LISTED & $\begin{array}{l}-0.479 \\
(-0.87)\end{array}$ & $\begin{array}{l}0.450 \\
(0.10)\end{array}$ & $\begin{array}{l}-1.844 \\
(-1.25)\end{array}$ & $\begin{array}{l}-32.06 \\
(-0.82)\end{array}$ & $\begin{array}{l}-2.338 \\
(-0.05)\end{array}$ & $\begin{array}{l}2.973 \\
(0.72)\end{array}$ & $\begin{array}{l}-5.311 \\
(-0.11)\end{array}$ & $\begin{array}{l}-0.249 \\
(-0.32)\end{array}$ & $\begin{array}{l}8.212 \\
(1.10)\end{array}$ \\
\hline LAMBDA & $\begin{array}{c}-0.00960 \\
(-0.13)\end{array}$ & $\begin{array}{l}-0.106 \\
(-0.21)\end{array}$ & $\begin{array}{l}-0.232 \\
(-1.10)\end{array}$ & $\begin{array}{l}5.079 \\
(1.12)\end{array}$ & $\begin{array}{l}12.04 \\
(1.39)\end{array}$ & $\begin{array}{l}-0.145 \\
(-0.34)\end{array}$ & $\begin{array}{l}12.18 \\
(1.43)\end{array}$ & $\begin{array}{l}-0.221^{*} \\
(-1.95)\end{array}$ & $\begin{array}{c}-1.758^{* *} \\
(-2.06)\end{array}$ \\
\hline LAMBDA*LISTED & $\begin{array}{c}0.924^{* *} \\
(2.15)\end{array}$ & $\begin{array}{l}9.024^{*} \\
(1.86)\end{array}$ & $\begin{array}{l}0.669 \\
(0.59)\end{array}$ & $\begin{array}{l}-49.80 \\
(-1.14)\end{array}$ & $\begin{array}{l}-36.79 \\
(-0.80)\end{array}$ & $\begin{array}{l}-2.027 \\
(-0.52)\end{array}$ & $\begin{array}{l}-34.76 \\
(-0.79)\end{array}$ & $\begin{array}{l}-0.324 \\
(-0.34)\end{array}$ & $\begin{array}{l}-13.90 \\
(-1.52)\end{array}$ \\
\hline COUNTRY DUMMIES & Yes & Yes & Yes & Yes & Yes & Yes & Yes & Yes & Yes \\
\hline Number of obs. & 93 & 93 & 91 & 92 & 93 & 93 & 93 & 93 & 93 \\
\hline R2 & 0.500 & 0.208 & 0.193 & 0.183 & 0.127 & 0.177 & 0.125 & 0.342 & 0.267 \\
\hline
\end{tabular}

Variable definitions (standard deviations and means are computed over the period 1999-2005): SDROA= standard deviation of the return on average assets; $S D R O E=$ standard deviation of the return on average equity , $M_{-} L L P=$ mean of the ratio of loan loss provisions to net loans; $Z=\mathrm{Z}$-score; $Z P=\mathrm{ZP}$-score; $Z P 1=$ measure of bank portfolio risk; $Z P 2=$ measure of leverage risk; $M \_R O A=$ mean of the return on average asset; $M \_R O E=$ mean of the return on average equity; $M L N T A=$ mean of the natural logarithm of total asset; $M O E O U I T Y=$ mean of the ratio of equity to total assets orthogonalized with TA; $M$ DEPOSIT = mean of the ratio of deposits to total assets; $L I S T E D=$ a dummy variable which takes the value of one if the bank is listed on the stock market and zero otherwise; $L A M B D A$ is the inverse Mills ratio estimated for each bank from the first-stage Probit model. The variables FAMILY, COMPANY and BANK represent the percentage of stock held respectively by families/individuals, non-financial companies and banks. We also include dummy variables to account for country specific effects. 
Table A6: Market discipline and influence of ownership structure on risk and profitability, cross-section OLS regressions

\begin{tabular}{|c|c|c|c|c|c|c|c|c|c|}
\hline & \multicolumn{3}{|c|}{ Risk measures } & \multicolumn{4}{|c|}{ Default Risk measures } & \multicolumn{2}{|c|}{ Profitability measures } \\
\hline & SDROA & SDROE & M_LLP & $\mathrm{Z}$ & $\mathrm{ZP}$ & ZP1 & ZP2 & M_ROA & M_ROE \\
\hline \multirow{2}{*}{$\operatorname{CONSTANT}\left(\beta_{0}\right)$} & 0.435 & 4.764 & $2.128^{* *}$ & $57.09^{* * *}$ & $90.72^{* *}$ & $6.317^{* *}$ & $84.41^{* *}$ & $1.880^{* * *}$ & $15.62^{* * *}$ \\
\hline & $(0.84)$ & $(0.75)$ & $(2.50)$ & $(2.80)$ & $(2.47)$ & $(2.42)$ & $(2.37)$ & $(3.55)$ & $(3.52)$ \\
\hline FAMILY $\left(\beta_{1}\right)$ & $\begin{array}{c}-0.00466 \\
(-1.38)\end{array}$ & $\begin{array}{c}-0.0810^{* *} \\
(-2.66)\end{array}$ & $\begin{array}{c}-0.0209^{*} \\
(-1.86)\end{array}$ & $\begin{array}{l}0.283 \\
(1.93)\end{array}$ & $\begin{array}{l}0.283 \\
(0.83)\end{array}$ & $\begin{array}{l}0.0146 \\
(-0.80)\end{array}$ & $\begin{array}{l}0.268 \\
(0.99)\end{array}$ & $\begin{array}{c}0.000322 \\
(-0.17)\end{array}$ & $\begin{array}{c}-0.000599 \\
(-0.37)\end{array}$ \\
\hline $\operatorname{COMPANY}\left(\beta_{2}\right)$ & $\begin{array}{c}-0.00253 \\
(-0.78)\end{array}$ & $\begin{array}{l}-0.0109 \\
(-0.26)\end{array}$ & $\begin{array}{l}-0.0112 \\
(-1.05)\end{array}$ & $\begin{array}{l}0.119 \\
(0.67)\end{array}$ & $\begin{array}{c}-0.00461 \\
(-0.03)\end{array}$ & $\begin{array}{c}-0.0246 \\
(-1.37)\end{array}$ & $\begin{array}{c}0.0200 \\
(0.12)\end{array}$ & $\begin{array}{c}-0.000389 \\
(-0.10)\end{array}$ & $\begin{array}{l}-0.0321 \\
(-0.67)\end{array}$ \\
\hline $\operatorname{BANK}\left(\beta_{3}\right)$ & $\begin{array}{c}-0.000124 \\
(-0.05)\end{array}$ & $\begin{array}{l}-0.0177 \\
(-0.64)\end{array}$ & $\begin{array}{c}-0.00933 \\
(-1.07)\end{array}$ & $\begin{array}{l}0.161 \\
(1.03)\end{array}$ & $\begin{array}{c}0.0473 \\
(0.33) \\
\end{array}$ & $\begin{array}{c}-0.00462 \\
(-0.26)\end{array}$ & $\begin{array}{c}0.0519 \\
(0.41)\end{array}$ & $\begin{array}{c}-0.000950 \\
(-0.37)\end{array}$ & $\begin{array}{c}-0.0129 \\
(-0.49)\end{array}$ \\
\hline FAMILY*DISCIPLINE $\left(\beta_{4}\right)$ & $\begin{array}{l}0.0240 \\
(0.96)\end{array}$ & $\begin{array}{l}-0.388 \\
(-0.62)\end{array}$ & $\begin{array}{c}-0.0120 \\
(-0.26)\end{array}$ & $\begin{array}{l}-3.613^{*} \\
(-1.89)\end{array}$ & $\begin{array}{l}-1.963 \\
(-0.82) \\
\end{array}$ & $\begin{array}{l}-0.315 \\
(-1.10)\end{array}$ & $\begin{array}{l}-1.647 \\
(-0.75)\end{array}$ & $\begin{array}{c}-0.0344 \\
(-0.91)\end{array}$ & $\begin{array}{l}-0.558^{* *} \\
(-2.07)\end{array}$ \\
\hline COMPANY*DISCIPLINE $\left(\beta_{5}\right)$ & $\begin{array}{c}-0.00105 \\
(-0.24)\end{array}$ & $\begin{array}{l}0.112 \\
(0.73)\end{array}$ & $\begin{array}{c}0.00815 \\
(0.62)\end{array}$ & $\begin{array}{l}0.155 \\
(0.69)\end{array}$ & $\begin{array}{c}-0.0597 \\
(-0.21) \\
\end{array}$ & $\begin{array}{c}-0.00250 \\
(-0.06)\end{array}$ & $\begin{array}{c}-0.0572 \\
(-0.22)\end{array}$ & $\begin{array}{c}-0.00369 \\
(-0.58)\end{array}$ & $\begin{array}{l}0.0391 \\
(0.71)\end{array}$ \\
\hline BANK*DISCIPLINE $\left(\beta_{6}\right)$ & $\begin{array}{c}-0.00296 \\
(-0.91)\end{array}$ & $\begin{array}{c}-0.00628 \\
(-0.15)\end{array}$ & $\begin{array}{c}-0.00204 \\
(-0.22)\end{array}$ & $\begin{array}{l}0.139 \\
(0.70)\end{array}$ & $\begin{array}{c}0.0663 \\
(0.21) \\
\end{array}$ & $\begin{array}{c}-0.0390 \\
(-0.90)\end{array}$ & $\begin{array}{l}0.105 \\
(0.38)\end{array}$ & $\begin{array}{c}-0.00187 \\
(-0.46)\end{array}$ & $\begin{array}{c}-0.0392 \\
(-1.07)\end{array}$ \\
\hline M_LNTA $\left(\beta_{8}\right)$ & $\begin{array}{c}0.0569^{* *} \\
(2.26)\end{array}$ & $\begin{array}{l}0.857^{* *} \\
(2.16)\end{array}$ & $\begin{array}{c}-0.0658 \\
(-1.11)\end{array}$ & $\begin{array}{c}-5.144^{* * *} \\
(-2.77)\end{array}$ & $\begin{array}{l}-6.686^{* *} \\
(-2.14)\end{array}$ & $\begin{array}{l}-0.311 \\
(-1.45)\end{array}$ & $\begin{array}{l}-6.374^{* *} \\
(-2.10)\end{array}$ & $\begin{array}{c}-0.0591^{*} \\
(-1.66)\end{array}$ & $\begin{array}{l}-0.0817 \\
(-0.29)\end{array}$ \\
\hline M_OEQUITY $\left(\beta_{9}\right)$ & $\begin{array}{c}0.0647^{* * *} \\
(7.14)\end{array}$ & $\begin{array}{l}0.0123 \\
(0.17)\end{array}$ & $\begin{array}{c}-0.0527^{* *} \\
(-1.97)\end{array}$ & $\begin{array}{l}-0.216 \\
(-0.52)\end{array}$ & $\begin{array}{l}-0.892 \\
(-1.56)\end{array}$ & $\begin{array}{l}-0.121^{*} \\
(-1.79)\end{array}$ & $\begin{array}{l}-0.771 \\
(-1.46)\end{array}$ & $\begin{array}{c}0.0482^{* * *} \\
(2.77)\end{array}$ & $\begin{array}{l}-0.141 \\
(-1.57)\end{array}$ \\
\hline M_DEPOSIT $\left(\beta_{10}\right)$ & $\begin{array}{c}-0.000872 \\
(-0.24)\end{array}$ & $\begin{array}{c}-0.0280 \\
(-0.70)\end{array}$ & $\begin{array}{c}-0.00514 \\
(-0.82)\end{array}$ & $\begin{array}{c}0.0456 \\
(0.24)\end{array}$ & $\begin{array}{l}-0.200 \\
(-1.01)\end{array}$ & $\begin{array}{c}-0.0229 \\
(-1.27)\end{array}$ & $\begin{array}{l}-0.177 \\
(-0.94)\end{array}$ & $\begin{array}{c}-0.00384 \\
(-1.07)\end{array}$ & $\begin{array}{c}-0.0133 \\
(-0.39)\end{array}$ \\
\hline DISCIPLINE $\left(\beta_{7}\right)$ & $\begin{array}{c}0.0360 \\
(0.17)\end{array}$ & $\begin{array}{l}-1.983 \\
(-0.60)\end{array}$ & $\begin{array}{l}-0.339 \\
(-0.48)\end{array}$ & $\begin{array}{l}-4.698 \\
(-0.38)\end{array}$ & $\begin{array}{l}8.936 \\
(0.38)\end{array}$ & $\begin{array}{l}1.971 \\
(0.51)\end{array}$ & $\begin{array}{l}6.965 \\
(0.34)\end{array}$ & $\begin{array}{l}0.395 \\
(1.06)\end{array}$ & $\begin{array}{l}2.535 \\
(0.89)\end{array}$ \\
\hline COUNTRY DUMMIES & Yes & Yes & Yes & Yes & Yes & Yes & Yes & Yes & Yes \\
\hline Risk level to reject $\beta_{1}+\beta_{4}=0$ & 0.419 & 0.460 & 0.528 & $0.0859^{*}$ & 0.455 & 0.253 & 0.506 & 0.356 & $0.0364 * *$ \\
\hline Risk level to reject $\beta_{2}+\beta_{5}=0$ & 0.291 & 0.488 & 0.745 & 0.102 & 0.788 & 0.467 & 0.858 & 0.483 & 0.874 \\
\hline Risk level to reject $\beta_{3}+\beta_{6}=0$ & 0.137 & 0.438 & $0.0123 * *$ & $0.0466 * *$ & 0.706 & 0.324 & 0.554 & 0.384 & $0.0763 *$ \\
\hline Number of obs. & 247 & 247 & 244 & 245 & 247 & 247 & 247 & 247 & 246 \\
\hline $\mathrm{R} 2$ & 0.296 & 0.0869 & 0.106 & 0.124 & 0.0529 & 0.116 & 0.0509 & 0.305 & 0.150 \\
\hline
\end{tabular}

***, ** and * indicate significance at the $1 \%, 5 \%$ and $10 \%$ levels respectively. t-statistics are corrected for heteroskedasticity following White's methodology.

Variable definitions (standard deviations and means are computed over the period 1999-2005): SDROA= standard deviation of the return on average assets; $S D R O E=$ standard deviation of the return on average equity , $M_{-} L L P=$ mean of the ratio of loan loss provisions to net loans; $Z=Z$-score; $Z P=Z \mathrm{P}$-score; $Z P I=$ measure of bank portfolio risk; $Z P 2=$ measure of leverage risk; $M \_R O A=$ mean of the return on average asset; $M_{-} R O E=$ mean of the return on average equity; $M_{-} L N T A=$ mean of the natural logarithm of total asset; $M \_O E Q U I T Y=$ mean of the ratio of equity to total assets orthogonalizedwith TA; $M_{-}$DEPOSIT = mean of the ratio of deposits to total assets; DISCIPLINE = a dummy variable which takes the value of one if the bank holds more than the median value of the ratio of market debt plus uninsured deposits to total assets and zero otherwise; The variables FAMILY, COMPANY and BANK represent the percentage of stock held respectively by families/individuals, non-financial companies and banks. We also include dummy variables to account for country specific effects. 
Table A7. Influence of the nature of the main shareholder on risk, probability of default, and profitability (Model 1), cross-section OLS regressions

\begin{tabular}{|c|c|c|c|c|c|c|c|c|c|}
\hline & \multicolumn{3}{|c|}{ Risk measures } & \multicolumn{4}{|c|}{ Default Risk measures } & \multicolumn{2}{|c|}{ Profitability measures } \\
\hline & SDROA & SDROE & M_LLP & $\mathrm{Z}$ & $\mathrm{ZP}$ & $\mathrm{ZP1}$ & $\mathrm{ZP} 2$ & M_ROA & M_ROE \\
\hline CONSTANT & $\begin{array}{c}-0.0482 \\
(-0.07)\end{array}$ & $\begin{array}{l}-8.277 \\
(-0.69)\end{array}$ & $\begin{array}{l}2.869 \\
(1.57)\end{array}$ & $\begin{array}{l}60.14^{*} \\
(1.94)\end{array}$ & $\begin{array}{l}29.07 \\
(0.63)\end{array}$ & $\begin{array}{l}-2.010 \\
(-0.34)\end{array}$ & $\begin{array}{l}31.08 \\
(0.75)\end{array}$ & $\begin{array}{c}2.818^{* * *} \\
(3.66)\end{array}$ & $\begin{array}{c}23.40^{* * *} \\
(3.53)\end{array}$ \\
\hline FAMILY_OWNED & $\begin{array}{l}-0.220 \\
(-1.10)\end{array}$ & $\begin{array}{c}-5.555^{* *} \\
(-2.39)\end{array}$ & $\begin{array}{c}-1.106^{* *} \\
(-2.30)\end{array}$ & $\begin{array}{l}8.898 \\
(0.60)\end{array}$ & $\begin{array}{l}1.354 \\
(0.10)\end{array}$ & $\begin{array}{l}-1.233 \\
(-1.12)\end{array}$ & $\begin{array}{l}2.587 \\
(0.21)\end{array}$ & $\begin{array}{l}-0.257 \\
(-0.87)\end{array}$ & $\begin{array}{l}-2.039 \\
(-0.84)\end{array}$ \\
\hline COMPANY_OWNED & $\begin{array}{l}-0.146 \\
(-0.73)\end{array}$ & $\begin{array}{l}4.054 \\
(0.72)\end{array}$ & $\begin{array}{l}-0.574 \\
(-0.92)\end{array}$ & $\begin{array}{l}2.658 \\
(0.19)\end{array}$ & $\begin{array}{l}-4.438 \\
(-0.36)\end{array}$ & $\begin{array}{l}-1.519 \\
(-1.18)\end{array}$ & $\begin{array}{l}-2.919 \\
(-0.25)\end{array}$ & $\begin{array}{l}-0.161 \\
(-0.61)\end{array}$ & $\begin{array}{l}-0.564 \\
(-0.19)\end{array}$ \\
\hline BANK_OWNED & $\begin{array}{c}-0.0262 \\
(-0.16)\end{array}$ & $\begin{array}{l}-1.045 \\
(-0.53)\end{array}$ & $\begin{array}{l}-0.762^{*} \\
(-1.72)\end{array}$ & $\begin{array}{r}10.39 \\
(0.89)\end{array}$ & $\begin{array}{l}4.429 \\
(0.40)\end{array}$ & $\begin{array}{l}-0.450 \\
(-0.33)\end{array}$ & $\begin{array}{l}4.879 \\
(0.49)\end{array}$ & $\begin{array}{c}-0.0942 \\
(-0.54)\end{array}$ & $\begin{array}{l}-1.138 \\
(-0.63)\end{array}$ \\
\hline M_LNTA & $\begin{array}{c}0.0635^{*} \\
(1.90)\end{array}$ & $\begin{array}{l}1.177^{*} \\
(1.84)\end{array}$ & $\begin{array}{l}-0.120 \\
(-1.33)\end{array}$ & $\begin{array}{c}-4.390^{* *} \\
(-2.19)\end{array}$ & $\begin{array}{l}-3.671 \\
(-1.23)\end{array}$ & $\begin{array}{l}0.0831 \\
(0.30)\end{array}$ & $\begin{array}{l}-3.754 \\
(-1.33)\end{array}$ & $\begin{array}{c}-0.0900^{* *} \\
(-2.08)\end{array}$ & $\begin{array}{l}-0.310 \\
(-0.96)\end{array}$ \\
\hline M_OEQUITY & $\begin{array}{c}0.0663^{* * *} \\
(6.84)\end{array}$ & $\begin{array}{c}0.00803 \\
(0.09)\end{array}$ & $\begin{array}{c}-0.0531^{* *} \\
(-1.99)\end{array}$ & $\begin{array}{l}-0.293 \\
(-0.71)\end{array}$ & $\begin{array}{l}-0.926 \\
(-1.57)\end{array}$ & $\begin{array}{l}-0.102^{*} \\
(-1.74)\end{array}$ & $\begin{array}{l}-0.823 \\
(-1.49)\end{array}$ & $\begin{array}{c}0.0459^{* *} \\
(2.53)\end{array}$ & $\begin{array}{l}-0.127 \\
(-1.39)\end{array}$ \\
\hline M_DEPOSIT & $\begin{array}{c}-0.00222 \\
(-1.04)\end{array}$ & $\begin{array}{c}-0.00505 \\
(-0.13)\end{array}$ & $\begin{array}{c}-0.0113 \\
(-1.30)\end{array}$ & $\begin{array}{l}0.137 \\
(0.68)\end{array}$ & $\begin{array}{c}0.0754 \\
(0.28)\end{array}$ & $\begin{array}{c}-0.0671^{* * *} \\
(-3.06)\end{array}$ & $\begin{array}{l}0.142 \\
(0.56)\end{array}$ & $\begin{array}{c}-0.00701^{* *} \\
(-2.32)\end{array}$ & $\begin{array}{c}-0.101^{* * *} \\
(-3.78)\end{array}$ \\
\hline LISTED & $\begin{array}{l}0.308 \\
(0.69)\end{array}$ & $\begin{array}{l}5.368 \\
(0.97)\end{array}$ & $\begin{array}{l}-0.300 \\
(-0.42)\end{array}$ & $\begin{array}{l}-2.363 \\
(-0.12)\end{array}$ & $\begin{array}{l}25.70 \\
(0.83)\end{array}$ & $\begin{array}{l}8.642^{*} \\
(1.93)\end{array}$ & $\begin{array}{r}17.06 \\
(0.62)\end{array}$ & $\begin{array}{l}-0.438 \\
(-1.07)\end{array}$ & $\begin{array}{r}0.949 \\
(0.23) \\
\end{array}$ \\
\hline LAMBDA & $\begin{array}{l}0.0447 \\
(0.99)\end{array}$ & $\begin{array}{l}1.262 \\
(1.42)\end{array}$ & $\begin{array}{l}-0.124 \\
(-0.62)\end{array}$ & $\begin{array}{l}1.048 \\
(0.35)\end{array}$ & $\begin{array}{l}6.424 \\
(1.40)\end{array}$ & $\begin{array}{c}0.00419 \\
(0.01)\end{array}$ & $\begin{array}{l}6.420 \\
(1.46)\end{array}$ & $\begin{array}{c}-0.181^{* * *} \\
(-2.84)\end{array}$ & $\begin{array}{c}-2.102^{* * *} \\
(-3.23)\end{array}$ \\
\hline LAMBDA*LISTED & $\begin{array}{l}-0.207 \\
(-0.59)\end{array}$ & $\begin{array}{l}-4.171 \\
(-0.89)\end{array}$ & $\begin{array}{l}-0.159 \\
(-0.46)\end{array}$ & $\begin{array}{l}4.145 \\
(0.30)\end{array}$ & $\begin{array}{l}-14.89 \\
(-0.67)\end{array}$ & $\begin{array}{l}-5.779^{*} \\
(-1.79)\end{array}$ & $\begin{array}{l}-9.110 \\
(-0.47)\end{array}$ & $\begin{array}{l}0.158 \\
(0.42)\end{array}$ & $\begin{array}{l}-1.696 \\
(-0.54)\end{array}$ \\
\hline COUNTRY DUMMIES & Yes & Yes & Yes & Yes & Yes & Yes & Yes & Yes & Yes \\
\hline Number of obs. & 244 & 244 & 241 & 242 & 244 & 244 & 244 & 244 & 243 \\
\hline R2 & 0.289 & 0.0744 & 0.0924 & 0.104 & 0.0549 & 0.153 & 0.0520 & 0.301 & 0.221 \\
\hline
\end{tabular}

***,** and * indicate significance, respectively, at the 1\%,5\% and 10\%levels respectively. t-statistics are corrected for heteroskedasticity following White's methodology. Variable definitions (standard deviations and means are computed over the period 1999-2005): SDROA= standard deviation of the return on average assets; SDROE = standard deviation of the return on average equity , $M L L P=$ mean of the ratio of loan loss provisions to net loans; $Z=\mathrm{Z}$-score; $Z P=\mathrm{ZP}$-score; $Z P I=$ measure of bank portfolio risk; $Z P 2=$ measure of leverage risk; $M R O A=$ mean of the return on average asset; $M R O E=$ mean of the return on average equity; $M L N T A=$ mean of the natural logarithm of total asset; $M \_O E Q U I T Y=$ mean of the ratio of equity to total assets orthogonalized with TA; $M \_D E P O S I T=$ mean of the ratio of deposits to total assets; $L I S T E D=$ a dummy variable which takes the value of one if the bank is listed on the stock market and zero otherwise; $L A M B D A$ is the inverse Mills ratio estimated for each bank from the first-stage Probit model. We also include dummy variables to account for country specific effects. FAMILY-OWNED, COMPANY-OWNED and BANKOWNED are dummy variables which take the value of one when ownership is at least equal to $50 \%$ of total equity and 0 otherwise. 


\section{Appendix 2}

Our Model 1 is defined as:

$\mathrm{Y}_{\mathrm{i}}=\alpha_{0}^{\prime}+\alpha_{j}^{\prime} \sum_{\mathrm{j}=1}^{5} \mathrm{C}_{\mathrm{ji}}+\alpha_{6} \mathrm{Z}_{\mathrm{i}}+\varepsilon_{\mathrm{i}}$

with $\mathrm{C}_{1 \mathrm{i}}=$ MANAGER $_{\mathrm{i}} ; \mathrm{C}_{2 \mathrm{i}}=$ FAMILY $_{\mathrm{i}} ; \mathrm{C}_{3 \mathrm{i}}=$ COMPANY $_{\mathrm{i}} ; \mathrm{C}_{4 \mathrm{i}}=\mathrm{BANK}_{\mathrm{i}} ; \mathrm{C}_{5 \mathrm{i}}=$ INSTITUT $_{\mathrm{i}}$ and $\mathrm{Z}_{\mathrm{i}}$ is a vector of control variables.

As we have $\mathrm{C}_{5 \mathrm{i}}=100-\sum_{\mathrm{j}=1}^{4} \mathrm{C}_{\mathrm{ji}}$, we can rewrite Model 1 as following ${ }^{27}$ :

$$
\begin{aligned}
Y_{i}=\alpha_{0}^{\prime} & +\sum_{j=1}^{4} \alpha_{j}^{\prime} C_{j i}+\alpha_{j}^{\prime}\left(100-\sum_{j=1}^{4} C_{j i}\right)+\alpha_{6} Z_{i}+\varepsilon_{i} \\
= & \left(\alpha_{0}^{\prime}+100 \alpha_{5}^{\prime}\right)+\sum_{j=1}^{4}\left(\alpha_{j}^{\prime}-\alpha_{5}^{\prime}\right) C_{j i}+\alpha_{6} Z_{i}+\varepsilon_{i}
\end{aligned}
$$

We can then estimate the following Model:

$$
Y_{i}=\alpha_{0}+\sum_{j=1}^{4} \alpha_{j} C_{j i}+\alpha_{6} Z_{i}+\varepsilon_{i}
$$

with $\quad \alpha_{0}=\alpha_{0}^{\prime}+100 \alpha_{5}^{\prime}$ and $\alpha_{j}=\alpha_{j}^{\prime}-\alpha_{5}^{\prime}, j=1, . ., 4$.

The estimated coefficient associated with each ownership component $C_{j}$ has to be interpreted as the effect of a substitution between this component and the component $\mathrm{C}_{5 \mathrm{i}}$.

Regarding Model 2, we have

$$
\operatorname{RISK}_{\mathrm{i}}=\beta_{0}+\beta_{\mathrm{j}} \sum_{\mathrm{j}=1}^{5} \mathrm{C}_{\mathrm{ji}}+\gamma_{\mathrm{j}} \sum_{\mathrm{j}=1}^{5} \mathrm{C}_{\mathrm{ji}} * \operatorname{LISTED}_{\mathrm{i}}+\lambda \mathrm{Z}_{\mathrm{i}}+\varepsilon_{\mathrm{i}}
$$

We can rewrite Model 2 as following:

$$
\begin{aligned}
\operatorname{RISK}_{\mathrm{i}} & =\beta_{0}+\sum_{\mathrm{j}=1}^{4} \beta_{\mathrm{j}} \mathrm{C}_{\mathrm{ji}}+\beta_{5}\left(100-\sum_{\mathrm{j}=1}^{4} \mathrm{C}_{\mathrm{ji}}\right)+\sum_{\mathrm{j}=1}^{4} \gamma_{\mathrm{j}} \mathrm{C}_{\mathrm{ji}} * \operatorname{LISTED}_{\mathrm{i}}+\gamma_{5}\left(100-\sum_{\mathrm{j}=1}^{4} \mathrm{C}_{\mathrm{ji}}\right) * \operatorname{LISTED}_{\mathrm{i}}+\lambda \mathrm{Z}_{\mathrm{i}}+\varepsilon_{\mathrm{i}} \\
& =\left(\beta_{0}+100 \beta_{5}+100 \gamma_{5} * \operatorname{LISTED}_{\mathrm{i}}\right)+\sum_{\mathrm{j}=1}^{4}\left(\beta_{\mathrm{j}}-\beta_{5}\right) \mathrm{C}_{\mathrm{ji}}+\sum_{\mathrm{j}=1}^{4}\left(\gamma_{\mathrm{j}}-\gamma_{5}\right) \mathrm{C}_{\mathrm{ji}} * \operatorname{LISTED}_{\mathrm{i}}+\lambda \mathrm{Z}_{\mathrm{i}}+\varepsilon_{\mathrm{i}}
\end{aligned}
$$

\footnotetext{
${ }^{27}$ For 198 out of the 249 banks, the sum of the percentages of equity held by our five categories of shareholders is equal to $100 \%$.
} 